\title{
EFEITO DA SUPLEMENTAÇÃO COM ÁCIDO LINOLÉICO CONJUGADO (CLA) NA COMPOSIÇÃO DO LEITE, NO PERFIL DE ÁCIDOS GRAXOS E NA ATIVIDADE DE ENZIMAS LIPOGÊNICAS EM RATAS LACTANTES
}

\section{AMANDA APARECIDA HAYASHI}

Dissertação apresentada à Escola Superior de Agricultura “ Luiz de Queiroz ”, Universidade de São Paulo, para obtenção do título de Mestre em Agronomia, Área de Concentração: Ciência Animal e Pastagens.

P I R A C I C A B A

Estado de São Paulo - Brasil

Março - 2003 


\section{EFEITO DA SUPLEMENTAÇÃO COM ÁCIDO LINOLÉICO CONJUGADO (CLA) NA COMPOSIÇÃO DO LEITE, NO PERFIL DE ÁCIDOS GRAXOS E NA ATIVIDADE DE ENZIMAS LIPOGÊNICAS EM RATAS LACTANTES}

\section{AMANDA APARECIDA HAYASHI \\ Zootecnista}

Orientador: Prof. Dr. DANTE PAZZANESE D. LANNA

Dissertação apresentada à Escola Superior de Agricultura " Luiz de Queiroz", Universidade de São Paulo, para obtenção do título de Mestre em Agronomia, Área de Concentração: Ciência Animal e Pastagens.

P I R A C I C A B A

Estado de São Paulo - Brasil Março - 2003 


\section{Dados Internacionais de Catalogação na Publicação (CIP) DIVISÃO DE BIBLIOTECA E DOCUMENTAÇÃO - ESALQ/USP}

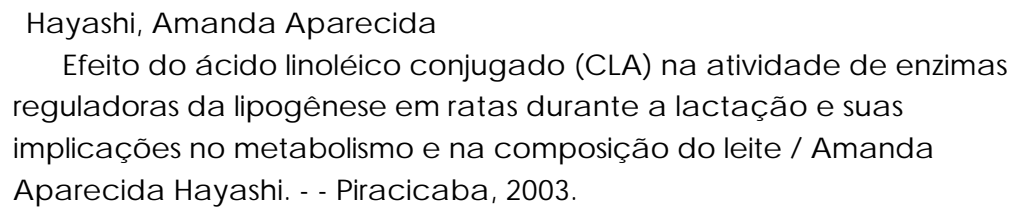

Dissertação (mestrado) - - Escola Superior de Agricultura Luiz de Queiroz, 2003.

Bibliografia.

1. Ácido linoléico 2. Composição corporal 3. Enzimas 4. Meta bolismo animal I. Título 
“Aonde quer que eu vá estarei sempre procurando o mundo em caminhos fora do mundo" Maria Dolores Wanderley

Aos meus pais, Paulo e Ivaci, pelo amor incondicional e generosidade. À minha avó (in memorian), por valorizar o substancial da vida. 


\section{AGRADECIMENTOS}

Ao professor Dr. Dante Pazzanese Duarte Lanna pela oportunidade de trabalharmos juntos; À minha irmã, Flávia, pelo otimismo e alegria contagiante;

À minha irmã, Patrícia, pela força e companheirismo; À minha madrinha, Márcia, pelo apoio;

Ao Sérgio Raposo, pela amizade e grande ajuda durante toda a condução deste trabalho;

À minha amiga, Andréa, pela fiel amizade;

Ao amigo, Marco Antônio, pela paciência e bom humor durante estes anos de convivência;

Aos doutorandos, Dimas, Rodrigo e Biológico pelos conselhos;

Aos mestrandos, Juliano, Liana que tornaram o ambiente de trabalho tão agradável quanto possível;

Aos eternos estagiários, Eric e Oscar ;

À Marina pela ajuda nas ordenhas.

Aos ex-companheiros de laboratório, Fernanda, Eduardo, André e Max;

À técnica de laboratório e secretária, Tuka e Ana.

À CAPES pela concessão da bolsa. 


\section{SUMÁRIO}

\section{Página}

LISTA DE FIGURAS....................................................................... vii

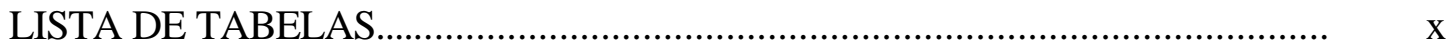

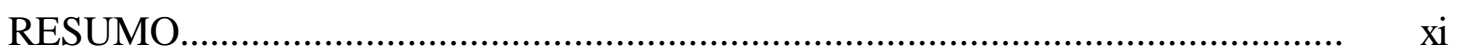

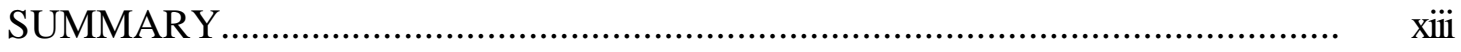

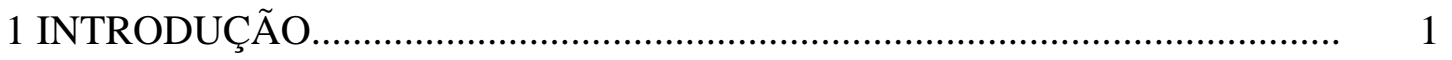

2 REVISÃO DE LITERATURA............................................................. 3

2.1 Descoberta do CLA............................................................................ 3

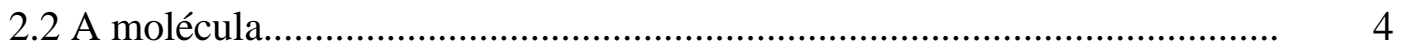

2.3 Produção do CLA................................................................................... 5

2.3.1 Produção de CLA no rúmen.................................................... 5

2.3.2 Síntese de CLA via Estearoil-CoA dessaturase............................... 7

2.4 Efeitos do CLA.................................................................................. $\quad 10$

2.4.1 Efeitos do CLA na composição corporal........................................ 10

2.4.2 Efeitos do CLA na carcinogênese.................................................. 15

2.4.3 CLA e síntese de gordura na glândula mamária................................. 19

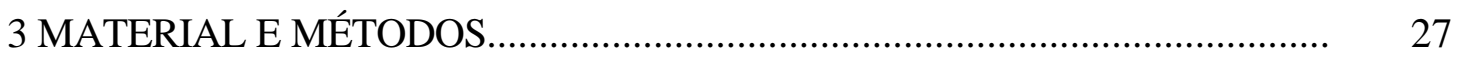

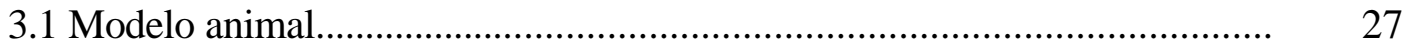

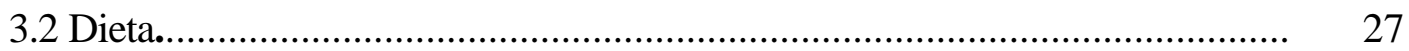

3.3 Consumo de Alimento...................................................................... 29 
3.4 Ganho de peso dos animais....................................................................... 29

3.5 Coleta de material................................................................................ $\quad 30$

3.5.1 Parâmetros Plasmáticos.................................................................... $\quad 30$

3.5.2 Avaliação da composição do leite....................................................... 30

3.5.3 Ensaio das atividades enzimáticas.................................................... 32

3.5.3.1 Preparação das amostras............................................................... 32

3.5.3.2 Ensaio da atividade enzimática da FAS.......................................... 32

3.5.3.3 Ensaio da atividade enzimática da G6PDH e 6PGDH................... 32

3.5.3.4 Ensaio da atividade enzimática da NADP-malato desidrogenase............................................................................... 33

3.5.3.5 Teor de proteína........................................................................... 33

3.6 Análise estatística................................................................................... 33

4 RESULTADOS E DISCUSSÃO.............................................................

4.1 Consumo de alimentos e Ganho de peso das fêmeas.................................... 35

4.2 Peso da Progênie...................................................................................... 37

4.3 Parâmetros Plasmáticos................................................................................ 40

4.4 Concentração de lipídeos totais no leite............................................................ 41

4.5 Perfil de ácidos graxos do leite.................................................................

4.6 Atividades enzimáticas: Glândula Mamária, Fígado e Tecido

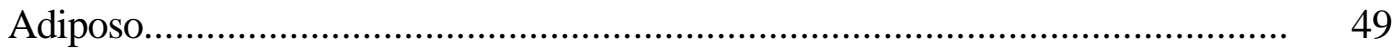

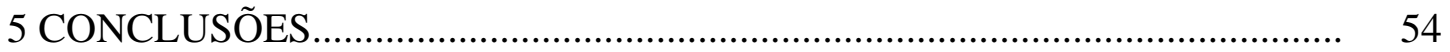

REFERÊNCIAS BIBLIOGRÁFICAS......................................................... 55 


\section{LISTA DE FIGURAS}

Página

1 Estrutura dos isômeros do CLA trans-10, cis-12; cis-9, trans-11 e Ácido linoléico (cis-9, cis-12). Adaptado de Pariza et al. (2001)............................

2 Via metabólica proposta para biossíntese do C18:2 cis-9, trans-11.

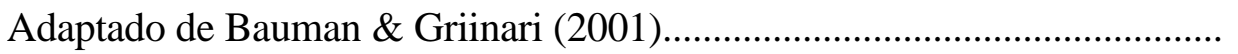

3a Relação entre a diminuição na produção da gordura do leite e doses de CLA trans-10, cis-12 infundidos no abomaso de vacas lactantes....................

3b Relação entre a diminuição na produção da gordura do leite e o conteúdo de CLA trans-10, cis-12 na gordura do leite.Adaptado de Peterson et al. (2002)

4 Representação esquemática do plano de trabalho realizado no experimento. 
5 Peso corporal (círculos) e consumo (quadrados) das ratas lactantes alimentadas por 15 dias com a dieta controle (símbolo vazado) ou CLA (símbolo cheio). O peso corporal $(n=8)$ e consumo $(n=8)$ foram analisados pelo teste $t$ ( $\mathrm{P}>0,10$ para ambas variáveis). Os pontos representam média \pm SE (erro padrão da média)...........................................................................

6 Peso da prole de fêmeas alimentadas com dieta controle (vazado) e CLA (cheio) ao longo da lactação. Valores de $\mathrm{P}$ estão apresentados na figura.

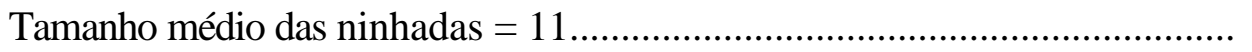

7 Relação entre a diminuição na concentração de gordura e o conteúdo de trans-10, cis-12 no leite no $15^{\circ}$ dia após a suplementação com CLA. Os

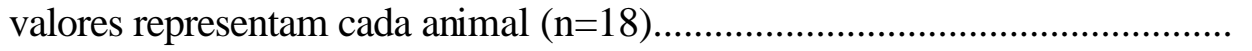

8 Efeito do CLA sobre teor de ácidos graxos de cadeia curta (C4:0-C10:0), média (C12:0-C16:0) e longa (C18:0) no leite. As barras representam média $\pm \mathrm{SE}, \mathrm{n}=9$ parcelas/ tratamento

9 Concentração ( $\mathrm{g} / 100 \mathrm{~g}$ de lipídios) dos isômeros do CLA trans-10, cis-12 e cis-9, trans-11 no leite das ratas controle e CLA. As barras representam

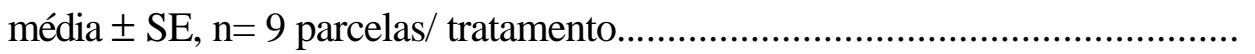

10 Eficiência estimada de recuperação no leite dos principais isômeros do CLA (trans-10, cis-12 e cis-9, trans-11). Cada coluna representa a média $( \pm \mathrm{SE})$ de transferência, calculada no $15^{\circ}$ dia de lactação para 9 ratas recebendo a 
dieta suplementada com 2,5\% de CLA............................................................

11 Teores de ácidos graxos saturados de cadeia curta (C4:0, C6:0, C8:0 e C10:0), média (C12:0, C14:0 e C16:0) e longa (C18:0). As linhas representam a proporção de ácidos graxos insaturados dentro de cada grupo de comprimento de cadeia, sendo uma delas presente no carbono 9. Os valores estão expressos como média $\pm \mathrm{SE}, \mathrm{n}=9$ parcelas/

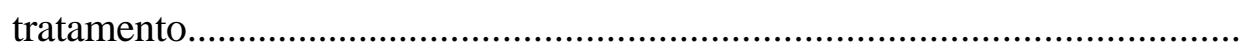

12 Atividade da FAS nos tecidos lipogênicos durante a lactação. Valores expressos em nanomoles de NADPH/min/mg de proteína, média \pm SE para a glândula mamária de 8 animais, fígado de 5 e tecido adiposo de 4 ................ 


\section{LISTA DE TABELAS}

Página

1 Concentrações plasmáticas de AGNE, Colesterol e TGA......................................

2 Porcentagem de gordura presente na matéria seca do leite................................

3 Perfil de ácidos graxos no leite no $15^{\circ}$ dia de lactação.......................................

4 Valores da atividade enzimática das enzimas FAS, G6PDH, 6PGDH e NADPmalato desidrogenase na glândula mamária, fígado e tecido

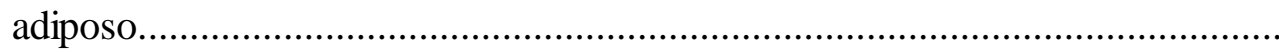




\title{
EFEITO DA SUPLEMENTAÇÃO COM ÁCIDO LINOLÉICO CONJUGADO (CLA) NA COMPOSIÇÃO DO LEITE, NO PERFIL DE ÁCIDOS GRAXOS E NA ATIVIDADE DE ENZIMAS LIPOGÊNICAS EM RATAS LACTANTES
}

\author{
ATIVIDADE DE ENZIMAS LIPOGENICAS EM RATAS LACTANIES
}

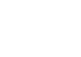


10,$12 ; 15 \%$ cis/trans 8,$10 ; 17 \%$ trans/trans 11,13 e $9 \%$ de outros isômeros. O tratamento com CLA reduziu a concentração de gordura do leite em $33 \%(\mathrm{P}<0,05)$. O perfil de ácidos graxos demonstrou que os efeitos do CLA foram mais pronunciados nos ácidos graxos sintetizados pela via de novo.. Além disso, as atividades das enzimas ácido graxo sintase (FAS), glicose 6-fosfato desidrogenase (G6PDH) e 6-fosfogluconato desidrogenase (6PGDH) foram reduzidas na glândula mamária e fígado após o tratamento com CLA. Em contraste, a atividade da enzima NADP-malato desidrogenase manteve-se inalterada nos animais tratados com CLA. A suplementação das fêmeas com CLA, propiciou significativa redução no crescimento da prole. Portanto, a suplementação da dieta de ratas lactantes com CLA, durante 15 dias de lactação, resultou em uma marcada redução no conteúdo de gordura e mudança ma composição de ácidos graxos, do leite. Os dados demonstram que os mecanismos através dos quais o CLA inibe a síntese de gordura do leite incluem diminuição da atividade das enzimas envolvidas na síntese de novo de ácidos graxos. 


\title{
EFFECTS OF CONJUGATED LINOLEIC ACID (CLA) SUPPLEMENTATION ON MILK COMPOSITION, FATTY ACIDS PROFILE AND LIPOGENIC ENZYMES ACTIVITY IN LACTATING RATS
}

\author{
Author: AMANDA APARECIDA HAYASHI \\ Adviser: Prof. Dr. DANTE PAZZANESE DUARTE LANNA
}

\section{SUMMARY}

CLA has a range of biological properties, including effects on lipid metabolism, milk and body composition in animals. This study investigated the effects of dietary CLA on lactating rats and development of the suckling rats. Dams were fed either with a control diet or a diet supplemented with $2.5 \%$ of calcium salts of CLA containing $60 \%$ of CLA (CLA-60, Church \& Dwight, Princeton, NJ) from parturition to the $15^{\text {th }}$ day post-partum. The CLA-60 contained different isomers of CLA (24\% cis/trans 9,11, 35\% cis/trans 10,12, $15 \%$ cis/trans $8,10,17 \%$ trans/trans 11,13 and $9 \%$ others). Treatment 
reduced milk fat content by $33 \%(\mathrm{P}<0.05)$. The fatty acid profile of milk suggest CLA effects were more pronounced on de novo synthesis. In accordance with that, the activities of fatty acid synthase (FAS), glucose 6-phosphate dehydrogenase (G6PDH) and 6-phophogluconate dehydrogenase (6PGDH) were reduced by CLA treatment in the mammary gland and liver. In contrast, the activity of NADP-malate dehydrogenase was unaffected. The CLA supplementation of the dams induced a significant reduction on the pups growth. Overall, feeding a diet supplemented with CLA to lactating rats for 15 days of lactation resulted in a marked reduction in milk fat content and in a shift in milk fatty acid composition. The data demonstrated that while inhibiting milk fat synthesis, CLA decreased activities of enzymes involved on de novo fatty acid synthesis. 


\section{INTRODUÇÃO}

O CLA compreende um conjunto de isômeros posicionais e geométricos do ácido linoléico (18:2) os quais têm apenas uma ligação simples entre as insaturações. Embora possam existir diversos isômeros possíveis com esta característica, dois deles (cis-9, trans-11 e trans-10, cis-12) tem despertado grande interesse em função dos seus efeitos biológicos já identificados. O CLA suplementado na dieta de vacas lactantes ou infundido diretamente no abomaso age como um nutriente capaz de reduzir a secreção de gordura no leite (Chouinard et al., 1999a). Da mesma forma, o CLA afeta a deposição de gordura na carcaça de animais em crescimento, como camundongos e suínos (Park et al., 1999; Ostrowska et al., 1999). A maior parte dos experimentos conduzidos tem utilizado suplementos comerciais contendo uma mistura de isômeros do CLA. Porém, sabe-se hoje que o isômero que afeta o metabolismo lipídico, sendo o responsável pela inibição da secreção da gordura do leite e pela redução da gordura na carcaça é o trans10, cis-12. O isômero cis-9, trans-11 não exerce efeitos sob este parâmetro (Baumgard et al.,2000a) porém, está relacionado com a inibição do crescimento de tumores e com a modulação da resposta imune (Pariza et al., 2001).

Os mecanismos pelos quais o isômero trans-10, cis-12 altera o metabolismo lipídico ainda não foram completamente elucidados. A produção de gordura do leite depende de ácidos graxos sintetizados de novo e dos ácidos graxos pré-formados oriundos da dieta ou da mobilização das reservas corporais. Possíveis pontos de regulação incluem, como por exemplo, o transporte intracelular de ácidos graxos, a dessaturação destes, a síntese de triglicerídeos e a formação e secreção do triglicerídio e da gota lipídica. Infusões de trans-10, cis-12 no abomaso de vacas lactantes reduziram a secreção de gordura do leite e foram acompanhadas por uma redução na quantidade 
secretada de todos os ácidos graxos. Porém, a magnitude da redução dos ácidos graxos sintetizados pela via de novo foi maior, sugerindo possíveis efeitos do CLA na expressão gênica de enzimas lipogênicas (Baumgard et al., 2002b).

O objetivo deste trabalho foi determinar se, como em vacas, o CLA altera o metabolismo de lipídios em ratas em lactação (um modelo animal de baixo custo). Também se procurou avaliar os mecanismos pelos quais o CLA reduz a lipogênese durante a lactação verificando as alterações na composição lipídica do leite de ratas e seu efeito sobre o ganho de peso dos seus filhotes.

As seguintes hipóteses foram testadas:

- Que em um modelo animal mais simples (menor custo, manejo e tempo de ensaio menores) e de baixa variação individual, a ação do CLA ocorre de maneira semelhante àquela em animais de interesse econômico;

- O CLA afeta a composição lipídica do leite dos animais;

- As alterações no metabolismo de lipídios, causadas pelo CLA, afetam o crescimento da progênie;

- O CLA afeta a síntese de ácidos graxos de maneira não homogênea, portanto alterando o perfil de ácidos graxos do leite e

- O CLA modifica a atividade de enzimas lipogênicas, em alguns tecidos, durante a lactação. 


\section{REVISÃO DE LITERATURA}

\subsection{Descoberta do CLA}

Pariza e colaboradores, na década de 70, sugeriram que a carne bovina grelhada possuía um componente carcinogênico (Pariza et al., 1979) . Neste período, estes mesmos autores buscavam identificar este componente. Já, em 1983, Pariza e colaboradores observaram que extratos da carne bovina possuía tanto componentes mutagênicos como também um componente com atividade antimutagênica e que este produto estava presente independente do cozimento, ao contrário do que se acreditava anteriormente (Pariza et al., 1983).

Pariza \& Hargraves, em 1985, demonstraram que este extrato da carne bovina era capaz de inibir a progressão do tumor em células epiteliais de camundongos. Somente após alguns anos, Ha et al. (1987) isolaram e caracterizaram este desconhecido componente antimutagênico da fração lipídica da carne, através das técnicas de cromatografia líquida de alta pressão (HPLC), cromatografia gasosa acoplada a espectrofotômetro de massa, espectrofotômetro ultra-violeta (espectro-UV) e espectroscopia de ressonância magnética nuclear. Neste trabalho, os autores descobriram que a fração isolada continha quatro isômeros derivados do ácido linoléico, sendo que cada um continha um sistema de dupla ligação conjugada, portanto sendo designados ácidos linoléicos conjugados (CLAs). Desde então, diversos estudos confirmaram a atividade anticarcinogênica do CLA, fato este que os levaram a serem considerados pela National Academy of Sciences como os únicos ácidos graxos que, indubitavelmente, são capazes de inibir a carcinogênese em animais experimentais. 


\subsection{A molécula}

O ácido linoléico conjugado (CLA) refere-se a uma mistura de isômeros posicionais e geométricos do ácido linoléico com duplas ligações conjugadas, isto é separadas apenas por uma ligação simples carbono-carbono (Figura 1). Há 56 possíveis isômeros geométricos e de posição do CLA (Yurawecz et al., 2001). Um dos isômeros, o cis-9, trans-11, foi identificado como um potente anticarcinogênico natural (Pariza \& Ha, 1990; p et al., 1991; Ip et al., 1994), enquanto o trans-10, cis-12 como um agente repartidor de nutrientes muito efetivo (McGuire et al., 1997, Park et al., 1997; Ostrowska et al., 1999). Estudos usando diferentes modelos animais relacionaram o CLA a vários outros efeitos positivos que poderiam favorecer a saúde humana, incluindo a redução na aterosclerose e prevenção e tratamento do diabetes mellitus não-dependente de insulina (Sebedio et al., 1999).

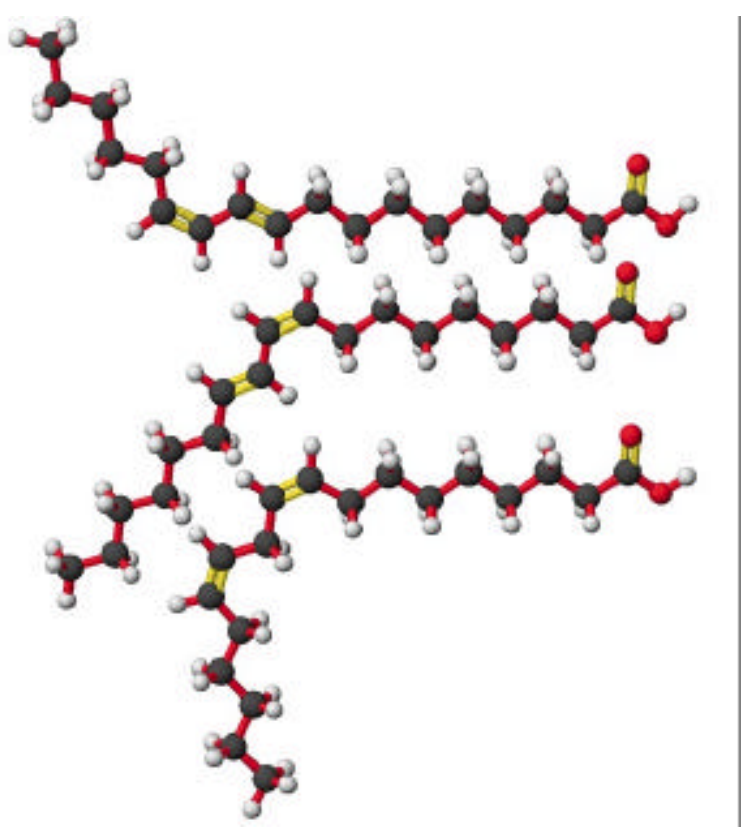

CLA trans-10, cis- 12

CLA cis- 9 , trans -11

Ácido Linoléico (cis-9, cis-12)

Figura 1 - Estrutura dos isômeros do CLA trans-10, cis-12; cis-9, trans-11 e Ácido linoléico (cis-9, cis-12). Adaptado de Pariza et al. (2001). 


\subsection{Produção do CLA}

O CLA pode ser formado no rúmen pela biohidrogenação incompleta de ácidos graxos poliinsaturados da dieta, mas também, endogenamente, através da dessaturação do ácido graxo C18:1 trans-11 por uma enzima presente na glândula mamária e tecido adiposo (Corl et al., 2001) chamada estearoil-CoA dessaturase ou Delta 9-dessaturase (SCD). Como o C18:1 trans-11 (ácido vacênico) é produzido principalmente através da biohidrogenação ruminal, este processo é o grande responsável pelo fato de que as maiores fontes de CLA são produtos derivados de ruminantes.

\subsubsection{Produção de CLA no rúmen}

Em ruminantes, o CLA é produzido normalmente por bactérias ruminais, como um intermediário do processo de biohidrogenação do ácido linoléico, sendo a Butyrivibrio fibrisolvens a mais conhecida (Kepler et al., 1966) (Figura 2). A cis-12, trans-11 linoleato isomerase (EC 5.2.1.5), enzima que catalisa a transformação de ácido linoléico em ácido vacênico, precisa de radicais carboxila $(\mathrm{COOH})$ livres para completar a reação (Kepler et al., 1966). Isto implica necessariamente em uma lipólise anterior à isomerização dos galactolipídios, fosfolipídios e triglicerídios da dieta.

Várias espécies de bactérias possuem um complexo de lipases capazes de hidrolisar as ligações éster dos ácidos graxos (Bauman \& Griinari, 2001). A isomerização inicial é seguida pela saturação da dupla cis-9 através da ação de uma redutase, resultando no ácido vacênico (C18:1 trans-11). Este é o isômero trans encontrado em maior quantidade na gordura do leite de ruminantes (Martin \& Jenkins 2002). A próxima etapa envolve uma redução subseqüente até a formação do ácido esteárico (C18:0). Esta via metabólica é a mais conhecida e a mais expressiva (Harfoot \& Hazlewood, 1988). Normalmente, a biohidrogenação acontece de forma completa, porém alguns produtos intermediários podem atravessar o rúmen e serem utilizados na síntese de lipídios no tecido mamário e adiposo (Figura 2). 


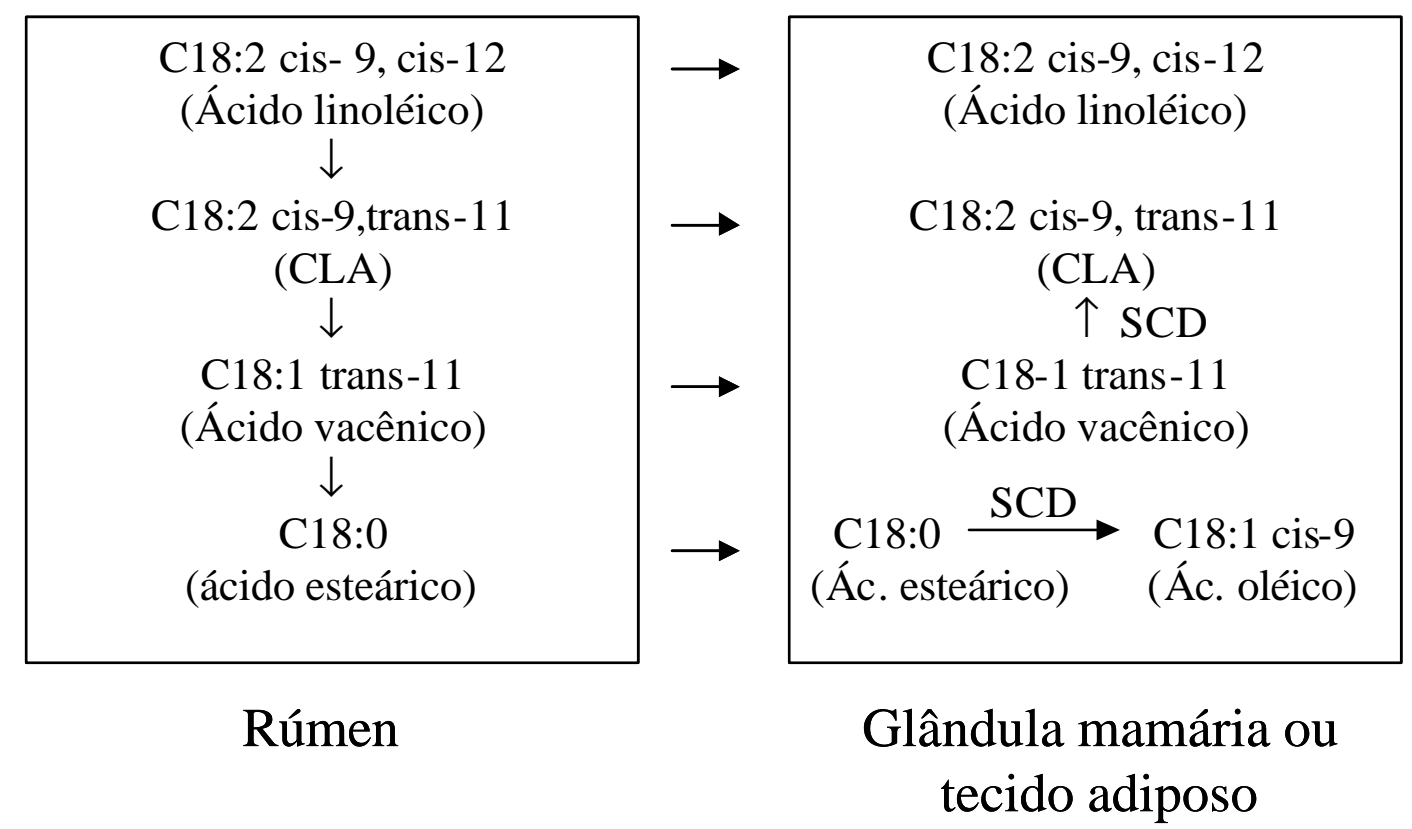

Figura 2 - Via metabólica proposta para biossíntese do C18:2 cis-9, trans-11. Adaptado de Bauman \& Griinari (2001).

Vários fatores podem influenciar a biohidrogenação ruminal e, conseqüentemente, a quantidade de ácidos graxos insaturados disponíveis para deposição no tecido adiposo ou secreção na gordura do leite. O aumento da quantidade de concentrado na dieta leva à diminuição da biohidrogenação, devido à queda do pH ruminal e diminuição da lipólise no rúmen (Chouinard et al., 1999b). Em monogástricos, os microrganismos do intestino também produzem CLA. Chin et al., (1994a) comprovaram que ratos convencionais, mas não ratos "germ free", são capazes de produzir CLA, utilizando o ácido linoléico como substrato para as bactérias intestinais.

Quando o CLA cis-9, trans-11 é absorvido pelo intestino, move-se para a corrente sanguínea e é absorvido pela glândula mamária para ser incorporado na gordura do leite. De maneira análoga, o ácido vacênico chega a glândula mamária, e, pela ação 
da enzima SCD pode ser transformado em cis-9, trans-11 (Griinari et al., 2000) (Figura 2).

\subsubsection{Síntese de CLA via Estearoil-CoA dessaturase}

A formação de ácidos graxos insaturados, nos mamíferos, ocorre através de enzimas denominadas dessaturases. Nos animais, as dessaturações vão ocorrer até o carbono 9, não podendo ocorrer além desse, devido à ausência das dessaturases delta 12 e delta 15, presentes somente em vegetais. Por este fato, o ácido linoléico é considerado ácido graxo essencial, devendo ser frnecido através da dieta por ser precursor essencial das prostaglandinas. A SCD introduz uma dupla ligação entre os carbonos 9 e 10 dos ácidos graxos. As reações catalisadas pelos sistemas de dessaturases são essenciais para manter as características de fluidez das membranas celulares e seus efeitos nas características de fluidez dos triglicerídios do leite são críticos para manter sua secreção normal (Perfield et al., 2002).

Para verificar a hipótese que o C18:1 trans-11 produzido, no rúmen, poderia ser convertido em CLA na glândula mamária pela ação da enzima SCD, Griinari et al. (2000) infundiram no abomaso de vacas em lactação, uma mistura de C18:1 trans-11 e C18:1 trans-12 (50\%-50\%). Estes autores observaram um aumento de $31 \%$ na concentração de CLA cis-9, trans-11 secretado no leite. Deste modo, puderam concluir que os animais realmente foram capazes de sintetizar endogenamente o CLA cis-9, trans-11, demonstrando que uma via ativa de síntese endógena existe. Em um segundo experimento, o objetivo foi verificar qual era a contribuição da síntese endógena de CLA via SCD. Através da infusão de óleo de esterculina (um potente inibidor da SCD), os autores verificaram que ocorria uma redução na concentração da gordura do leite e outros produtos da ação da SCD, os quais foram indicados por um aumento de duas a três vezes na relação da proporção dos ácidos graxos 14:0/14:1, 16:0/16:1 e 18:0/18:1. Utilizando a mudança na proporção de 14:0/14:1 como uma indicação da extensão da inibição da SCD, com o tratamento com óleo de esterculina, os autores estimaram que $64 \%$ do CLA na gordura do leite de ruminantes foi de origem endógena. Corroborando 
estes dados, Corl et al. (2001) demonstraram que o papel da síntese endógena de CLA é mais importante que a síntese pelas bactérias ruminais. Neste trabalho, ocorreu uma marcada redução de 60-65\% no CLA cis-9, trans-11 quando os animais receberam uma dieta suplementada com óleo de esterculina. Também foram observadas reduções de $84 \%, 59 \%$ e $46 \%$ para o C14:1 cis-9, C16:1 cis-9 e C18:1 cis-9, respectivamente. Da mesma forma, Kay et al. (2002) também suplementaram vacas sob regime de pastejo com óleo de esterculina com o intuito de verificar a contribuição desta via na produção de CLA. Sob as condições a que estes animais estavam submetidos, os autores estimaram que 87 a $100 \%$ do CLA cis-9, trans-11, na gordura do leite, foi de origem endógena. Estes autores ainda demonstraram, que os níveis de CLA cis-9, trans-11, no leite, poderiam ser aumentados quando os animais recebessem uma fonte de ácidos graxos trans C18:1, tal como óleo de girassol.

Na mesma linha de pesquisa, Piperova et al. (2002) realizaram um experimento fatorial 2x2, com vacas Holandesas sendo os tratamentos compostos de baixa forragem vs. alta forragem e $2 \%$ tampão vs. $0 \%$ de tampão adicionado. Estes autores concluíram que a secreção de CLA, no leite, foi maior $(\mathrm{P}<0,01)$ que a concentração do fluxo duodenal proporcionado por cada dieta. Isto foi devido a um aumento nos isômeros cis9, trans-11 e trans-7, cis-9 resultantes, na sua maioria, da síntese endógena via dessaturação (através da SCD) dos ácidos graxos trans, provenientes do rúmen.

Yang et al. (1999) demonstraram que a composição do tecido adiposo de bovinos alimentados a pasto tinha uma menor concentração de ácidos graxos saturados quando comparada à gordura de animais suplementados com uma dieta a base de grãos de algodão. A atividade da SCD correspondente foi $60-85 \%$ maior nos animais suplementados a pasto que os animais alimentados com grão. Os autores sustentam a hipótese que a redução na atividade da SCD foi devido aos ácidos graxos ciclopropenóides contidos na semente de algodão.

Lee et al. (1998) estudaram o efeito biológico do CLA na atividade da SCD. Na primeira parte do estudo eles suplementaram a dieta de camundongos com CLA (uma mistura de $42 \%$ cis-9, trans-11 e $44 \%$ trans-10, cis-12) e analisaram a expressão do RNA mensageiro (RNAm) hepático da SCD, a qual foi significativamente reduzida no 
tratamento com CLA. Na segunda etapa do experimento, hepatócitos de camundongo H2.35 foram testados, e o CLA gerado pelas bactérias do rúmen (esta preparação continha principalmente CLA cis-9, trans-11, sem o isômero trans-10, cis-12) não causou efeito na expressão do RNAm desta enzima. Baseado nestas informações, Lee et al. (1998) sugeriram que o isômero trans-10, cis-12 é o responsável pelos efeitos inibitórios do CLA na expressão da SCD. Corroborando esta hipótese, Park et al. (2000) testaram o efeito direto do CLA na atividade da SCD hepática, de camundongos, utilizando sômeros com alto grau de pureza. Os autores concluíram que uma ação direta inibitória do isômero trans-10 cis-12 ocorre na atividade desta enzima e que a dupla ligação na posição cis-12 é a mais importante nos efeitos inibitórios do CLA e este efeito é mais pronunciado quando ocorre ao mesmo tempo, a conjugação na posição trans-10.

Smith et al. (2002), estudando os efeitos da suplementação de CLA sobre a composição da gordura subcutânea de suínos observaram que existe um efeito do CLA na composição de ácidos graxos deste tecido, sendo que uma dieta suplementada com 1,5\% de CLA mostrou um aumento na concentração de ácidos graxos saturados quando comparada a uma dieta suplementada com 1,5\% de óleo de milho ou 1,5\% de sebo bovino. No tratamento com CLA, verificaram também, uma redução de $75 \%$ na atividade da SCD.

Choi et al. (2001) estudaram o efeito dos tratamentos com isômeros de CLA cis9, trans-11; trans-10, cis-12 e controle (albumina) nas linhagens celulares de hepatoblastoma de humanos, chamadas HepG2. Os autores verificaram que o isômero trans-10, cis-12 foi capaz de inibir a atividade da SCD nesta linhagem celular em $60 \%$ comparado ao controle, sem contudo afetar a taxa de transcrição do gene, como foi observado em células do fígado de roedores. Isto indica que nesta linhagem celular o CLA trans-10, cis-12 foi capaz de inibir mecanismos pós-traducionais, sem alterar os mecanismos transcricionais. Choi et al. (2002) estudaram o efeito dos isômeros do CLA cis-9, trans-11 e trans-10, cis-12 na expressão da SCD em linhagens de células tumorais de humanos; MCF-7 e MDA-MB-231. Utilizaram estas duas linhagens em função delas expressarem diferentes níveis da SCD, sendo menor na MDA-MB-231 e maior na MCF7. Os autores demonstraram que os dois isômeros de CLA foram capazes de regular a 
atividade da SCD nas células MDA-MB-231 através de uma redução na abundância da enzima. Já nas células MCF-7, o CLA apresentou um efeito direto na atividade da SCD.

\subsection{Efeitos do CLA}

\subsubsection{Efeitos do CLA na composição corporal}

Trabalhos têm mostrado que o CLA, principalmente o isômero trans-10, cis-12, tem efeito na composição corporal em diversos modelos animais. Existem vários mecanismos propostos para explicar esta redução no conteúdo de lipídios na carcaça. Entre estes, pode-se citar: 1) Diminuição da esterificação de ácidos graxos em triglicerídios; 2) Interferência do isômero trans-10, cis-12 no programa de diferenciação dos adipócitos; 3) Diminuição da lipogênese e 4) Aumento da lipólise. Estes mecanismos serão descritos a seguir.

Cook et al. (2000) verificaram que a suplementação com 5\% de CLA (18:2 trans10, cis-12, sem o cis-9, trans-11) por um período de 3 semanas, na dieta de camundongos, diminuiu em $82 \%$ a deposição de gordura subcutânea comparada à uma dieta com 5\% de ácido linoléico. Da mesma forma, Park et al. (1997) demonstraram que a suplementação com $0,5 \%$ de CLA (contendo o trans-10, cis-12) na dieta de ratos, diminuiu em $60 \%$ a deposição de gordura corporal dos animais e causou uma inibição direta da lipoproteína lpase em cultura de linhagem 3T3-L1 de adipócitos e um aumento significativo na concentração de glicerol no meio (22\%), que pode ser considerado como um indicativo do aumento da lipólise. Possivelmente, este aumento na lipólise foi acoplado a um aumento da oxidação de ácidos graxos nas células musculares e adipócitos, pois foi observado efeito do tratamento com CLA na atividade de carnitinapalmitoiltransferase (CPT) em ratos. Esta enzima seria o passo limitante para a betaoxidação. O efeito foi significativo para o tecido adiposo epididimal dos animais sem restrição alimentar e, no músculo esquelético para os ratos em jejum. Não houve efeito

para a CPT hepática. Portanto, o CLA aumentaria a beta-oxidação no músculo esquelético e tecido adiposo, mas não no fígado. Estes mesmos efeitos foram 
comprovados pelo mesmo grupo (Park et al., 1999) apenas para o isômero trans-10, cis12 , sendo que o cis-9, trans-11 não teve efeito nos parâmetros estudados.

Rahman et al. (2001) também observaram aumento na atividade da CPT no tecido adiposo marrom, tecido adiposo perirenal, tecido muscular e fígado em ratos OLEFT (modelo animal obeso/diabético) suplementados com 1\% de CLA na forma de triacilglicerol ou na forma de ácido graxo livre. Um aumento no gasto energético pode ser um mecanismo para diminuir a deposição de gordura em alguns animais tratados com CLA, mas ele não parece ser um mecanismo universal operante ao longo das espécies ou ainda mesmo um mecanismo consistente em camundongos (Evans et al., 2002). Estes autores observaram também uma redução no peso destes tecidos com exceção do fígado. Park et al. (1997), concluíram que o CLA estaria causando uma maior eficiência dos tecidos em oxidar ácidos graxos, com a finalidade de produzir calor. Este aumento na beta-oxidação poderia estar prevenindo o estoque de triglicerídios no tecido adiposo e desta forma estar reduzindo a massa adiposa dos animais.

Estudos conduzidos por DeLany et al. (1999) também demonstraram que o CLA reduziu a deposição de gordura corporal de camundongos, aumentou o conteúdo total de proteína na carcaça, além de ter aumentado os níveis de insulina sérica. Uma possível explicação encontrada por estes autores seria a alteração na sensibilidade ou resposta máxima dos tecidos à insulina (i.e. resistência à insulina). Assim, se os adipócitos tornarem-se resistentes à insulina após o tratamento com CLA, isto poderia explicar o paradoxal aumento da oxidação de ácidos graxos com o concomitante aumento da insulina plasmática. Se ao mesmo tempo o músculo esquelético permanecesse sensível à insulina, o aumento dos níveis de insulina poderia levar ao aumento na síntese de proteína e deposição muscular.

O CLA também exerce efeito na deposição de gordura em outros modelos animais. Em suínos, Ostrowska et al. (1999) estudaram o efeito de diferentes doses de CLA sobre a composição corporal destes animais. Estes autores demonstraram que a redução na espessura de gordura subcutânea foi diretamente ligada ao aumento das doses de CLA administrada a estes animais. Com a maior dose de CLA (1\% da dieta) os 
autores verificaram uma redução de $31 \%$ na deposição de gordura subcutânea. É provável que tenha ocorrido um efeito do CLA na lipogênese, uma vez que a dieta dos animais possuía elevadas quantidades de carboidratos e, assim, a síntese de novo poderia ser o mecanismo predominante da síntese de lipídios.

Outra possibilidade para a redução na deposição de gordura seria um aumento do gasto energético (West et al., 2000). Entretanto, em camundongos, estudos não observaram alterações na expressão dos genes das "uncoupling proteins" (UCP), na mitocôndria, particularmente da UCP-1, expressa exclusivamente no tecido adiposo marrom, considerada crítica para manter a temperatura interna em camundongos. Uma alteração na expressão dos genes destas proteínas seria esperada para explicar possíveis reduções na taxa de crescimento e deposição de gordura, sem concomitante redução no consumo de alimentos. Os autores encontraram somente alteração na expressão da UCP2, porém o papel desta UCP na termogênese parece ser bem pequeno, ou até mesmo insignificante (West et al., 2000).

$\mathrm{O}$ aumento no processo de apoptose nos adipócitos e processo de degradação celular poderia contribuir ou ainda ser a causa primária para a diminuição da deposição de gordura em animais tratados com CLA. Tsuboyama et al. (2000) alimentaram fêmeas de camundongos C57BL/6J com dietas semi-purificadas com ou sem CLA (1\%) e, após 11 dias, verificaram uma diminuição no tamanho dos adipócitos em 41\%, possivelmente causada por um aumento na expressão do fator de necrose tumoral (TNF- $\alpha$ ). Este fator causaria a apoptose dos adipócitos. $\mathrm{O}$ autor também mediu os níveis de RNAm de várias enzimas envolvidas na lipogênese em ratos suplementados com CLA após 5 meses. Estes animais apresentaram uma marcada diminuição na abundância dos RNAm da acetil CoA carboxilase (ACC) em $72 \%$ e de $88 \%$ da ácido graxo sintase (FAS), enzimas chaves de regulação da síntese de novo na glândula mamária e tecido adiposo. Entretanto, como a expressão de várias enzimas lipogênicas é controlada pelo fator de transcrição SREBP-1 (sterol regulatory element binding protein-1), o efeito do CLA na expressão do SREBP-1 também foi examinado. A abundância do RNAm deste fator de transcrição diminuiu com o tratamento e passou a ser $33 \%$ da abundância comparada ao grupo controle. 
Azain et al. (2000) estudaram os efeitos do CLA na mudança da composição corporal de ratos "Sprague Dawley" suplementados com CLA por um período mínimo de 7 dias. Estes autores verificaram que não houve efeito do CLA no ganho de peso dos animais ou na ingestão alimentar, porém, ocorreu uma redução de $32 \%$ na gordura subcutânea dos animais suplementados com doses de 0,5\% de CLA. Além disso, ocorreu uma redução de $44 \%$ na velocidade de deposição da gordura $(1,04 \mathrm{~g}$ x $0,58 \mathrm{~g}$ de ganho líquido, $\mathrm{P}<0,01)$. Os autores concluíram, também, que o efeito do CLA na redução da gordura corporal ocorreu na fase de diferenciação dos adipócitos, através de uma redução no tamanho, e não no número dos adipócitos. Esta teoria para redução da gordura corporal é consistente com mudanças metabólicas (diminuição da lipogênese e aumento da lipólise) reportadas previamente por Park et al. (1997).

Existem evidências (Evans et al., 2002) que o CLA pode exercer seu efeito na composição corporal através de um receptor nuclear, o receptor ativado proliferador de peroxissomo $(\operatorname{PPAR} \alpha)$. O PPAR $\alpha$ é um membro de uma família de receptores nucleares, que pertence a um tipo de fatores de transcrição regulatórios que são chaves na diferenciação dos adipócitos e no metabolismo lipídico. Este, quando ativado, pode modular a expressão gênica de numerosas enzimas que funcionam para transportar e oxidar ácidos graxos (Peters et al., 2001). Com o intuito de verificar se o CLA poderia estar induzindo enzimas que metabolizam lipídios através de uma ação no fator PPAR $\alpha$, Peters et al. (2001) conduziram um experimento para verificar o efeito do CLA administrado na dieta, de camundongos. Para isto, utilizaram camundongos nocauteados para este gene. Os ganhos de peso dos animais nocauteados e selvagens, suplementados com CLA, foram similares e um pouco menores que os animais controle. O conteúdo de gordura corporal foi reduzido nos tipos selvagem e nocauteados, suplementados com CLA de uma maneira similar. Adicionalmente, a suplementação com CLA resultou em maiores níveis de RNAm codificador de enzimas mitocondriais metabolizadoras de ácidos graxos e UCP-2 nos dois modelos suplementados com CLA7, o selvagem e o nocauteado. Estes resultados indicam que estas respostas induzidas pelo CLA parecem ser independentes de PPAR $\alpha$. 
Existem trabalhos associando um maior gasto energético com os efeitos do CLA na redução de gordura. Terpstra et al. (2002) realizaram um estudo para verificar o gasto energético em camundongos na fase de crescimento, submetidos ou não a uma dieta restrita e suplementados ou não com uma mistura de isômeros de CLA, por 39 dias. A energia presente na carcaça, na comida e fezes foi medida através de uma bomba calorimétrica. O CLA diminuiu a porcentagem de energia ingerida que foi armazenada na carcaça de 1,9 para $-2,3$ em animais não restritos e em 1,3 para $-2,9$ para animais restritos. Os valores negativos nos grupos recebendo CLA indicam que os animais ficaram em balanço energético negativo, ou seja, que nenhuma energia foi estocada, mas sim ocorreu um gasto energético pelos animais. Da mesma forma, os autores verificaram um aumento na energia perdida nas excretas dos animais recebendo CLA. A menor quantidade de energia estocada na carcaça foi um reflexo do aumento de $74 \%$ no gasto energético e um aumento da energia perdida nas fezes (26\%).

Em humanos os efeitos do tratamento com CLA não são claros. Por exemplo, o tratamento com CLA $(3,4 \%-6,8 \%)$ durante 3 meses reduziu a massa de tecido adiposo em adultos obesos e adultos acima do peso (Blankson et al., 2000). Brown et al. (2001) conduziram experimentos utilizando culturas primárias de células de estroma vascular de humanos para entre outros objetivos; verificar a resposta das células ao tratamento crônico com o isômero trans-10, cis-12 no conteúdo de triglicerídios celular, determinar se o efeito causado pelo CLA trans-10, cis-12 poderia ser revertido pelo ácido linoléico e verificar se uma possível redução no conteúdo de triglicerídios nas células seria devido a um aumento na lipogênese ou a um aumento na lipólise. No primeiro experimento eles verificaram que o conteúdo de triglicerídeos diminuía com doses de CLA de 1 a 10 $\mu \mathrm{mol} / \mathrm{L}$. No segundo experimento, as células tratadas com trans-10, cis-12 tinham $60 \%$ menos triglicerídios que as células controle. Interessante que, quando as culturas tratadas com $10 \mu \mathrm{mol} / \mathrm{L}$ de trans-10, cis-12 foram suplementadas com 10, 30 ou $100 \mu \mathrm{mol} / \mathrm{L}$ de ácido linoléico elas apresentaram mais triglicerídios que aquelas células tratadas somente com o isômero puro. Assim, o ácido linoléico mostrou-se capaz de reverter os efeitos causados pelo trans-10, cis12, restaurando o conteúdo de triglicerídios das células. Isto mostra claramente que os efeitos do CLA são reversíveis. No último 
experimento, eles verificaram que ocorreu uma redução na incorporação de glicose $\left[\mathrm{C}^{14}\right]$ nos lipídios totais, sendo que na maior dose de trans-10, cis-12 $(30 \mu \mathrm{mol} / \mathrm{L})$ esta redução foi de $80 \%$. Entretanto, nenhuma alteração foi observada em relação à lipólise. Estes dados sugerem que os efeitos antiobesidade reportados em humanos recebendo uma mistura de isômeros do CLA seriam devido a uma inibição da lipogênese pelo isômero trans-10, cis-12. Entretanto, é importante salientar que estudos em animais para testar os efeitos do CLA, na deposição de gordura, são conduzidos em animais na fase de crescimento e em humanos na fase adulta. Portanto, os estudos sobre os efeitos do CLA, em humanos, têm como objetivo principal a diminuição dos depósitos de gordura já formados (i.e. hipertrofia) e em animais em crescimento, a diminuição do número e, conseqüentemente, deposição de gordura (i.e. hiperplasia e hipertrofia).

\subsubsection{Efeitos do CLA na carcinogênese}

Existe evidência incontestável que o CLA é um efetivo agente anticarcinogênico em modelos animais. Embora o CLA tenha mostrado efeitos anticarcinogênicos em outros tecidos, como os da próstata, o desenvolvimento de tumores na glândula mamária parece ser particularmente sensível a intervenção do CLA. Segundo Ip (2001), o CLA estocado nos adipócitos poderia agir como um "fator parácrino" na regulação do crescimento das células epiteliais mamárias. Deste modo, dois principais isômeros cis-9, trans-11 e trans-10, cis-12 estariam envolvidos neste mecanismo. Ip et al. (2001) descobriram que além dos efeitos do CLA no epitélio mamário, ele também pode agir indiretamente, reduzindo a diferenciação das células do estroma mamário para um tipo de célula endotelial. Especificamente, esses autores descobriram que o CLA foi capaz de diminuir a capacidade das células do estroma mamário de formar redes de microcapilares in vitro (angiogênese). Esta capacidade do CLA em diminuir a angiogênese e modular a diferenciação das células do estroma mamário, pode contribuir para sua eficácia na inibição da carcinogênese mamária.

O primeiro trabalho na literatura, o qual mostra que a suplementação da dieta com CLA é efetivo na prevenção do câncer mamário, foi realizado por Ip et al. (1991). 
Estes autores observaram que ratas ingerindo $10 \mathrm{mg}$ de 7,12-dimetilbenzo-antraceno (substância que induz a carcinogênese) tiveram uma inibição de $32 \%$ no aparecimento do tumor mamário quando ingeriram 0,5\% de CLA na dieta e uma inibição de $60 \%$ numa dosagem de 1,5\% de CLA. Estas dietas foram iniciadas duas semanas antes da administração do carcinogênico e continuaram até o final do experimento. Ao longo deste experimento, os autores verificaram que embora as ratas fossem alimentadas com preparações de CLA, as quais continham uma mistura de isômeros, grande parte do cis9, trans-11 foi incorporado na fração fosfolipídica da membrana, e a partir daí sugeriram que este seria o isômero biologicamente ativo na inibição da carcinogênese.

Posteriormente, Ip et al. (1995) apresentaram evidências de que um contínuo suprimento de $1 \%$ de CLA na dieta de ratas, do período pós-desmama até o período da puberdade, foi suficiente para inibir o crescimento do tumor mamário. Este efeito foi prorrogado quando as fêmeas ininterruptamente continuaram recebendo CLA após a administração do reagente causador de tumores. Ip et al. (1997) confirmaram a teoria do experimento anterior, pois somente os animais que receberam doses de CLA durante todo experimento (20 semanas), tiveram uma redução de $70 \%$ no número total de tumores que neste experimento foi estimulado por leves doses de 7,12-dimetilbenzoantraceno. Estes autores também demonstraram que a incorporação de CLA foi muito maior nos lipídios neutros que nos fosfolipídios, verificando também que quando o CLA foi removido da dieta, os lipídios neutros e fsfolipídios dos animais suplementados com CLA retornaram ao seu valor basal. Esta seria uma possível explicação do porquê de um suprimento ininterrupto de CLA é necessário para manter a inibição da progressão do tumor.

Corroborando estes dados, Banni et al. (1999) mostraram que existe uma maior concentração de CLA nos tecidos que contém lipídios neutros (e.g. glândula mamária e gordura abdominal) que nos tecidos que contém fosfolipídios (e.g. fígado). Isto pode explicar o motivo pelo qual o CLA proporciona uma maior proteção da glândula mamária do que em outros tecidos. No epitélio mamário, existem estruturas morfológicas distintas denominadas "terminal end buds" (TEBs), as quais são sítios primários para indução química de carcinomas. Neste trabalho, houve uma gradativa 
redução da densidade dos TEBs com dosagens de CLA de 0,5-1,0\% e concomitante redução no aparecimento de tumores nestas mesmas dosagens.

Ip \& Scimeca (1997) descreveram que o efeito do CLA na inibição do tumor mamário é independente da dosagem de ácido linoléico na dieta. Estes autores suplementaram a dieta de roedores com dosagens de $0,5 \%$ a $2 \%$ de CLA, e a atividade anticarcinogênica do CLA foi máxima na dosagem de $1 \%$ de CLA. Porém, a incorporação de CLA nos lipídios e fosfolipídios acompanhou as doses de CLA. Isto sugere que o CLA deve ser convertido em algum metabólito ativo para ter propriedades anticarcinogênicas. Assim, a limitada capacidade desta via bioquímica poderia explicar a maximização do efeito protetor do CLA a 1\%, apesar do arescente acúmulo de CLA nos lipídios neutros a níveis maiores que este.

Posteriormente, Banni et al. (2001) realizaram dois experimentos com o objetivo de verificar se o ácido vacênico (C18:1 trans-11) é convertido eficientemente a ácido linoléico conjugado em ratos via ação da SCD e se o ácido vacênico poderia substituir o CLA como um agente anticarcinogênico. Em geral, as concentrações de CLA e seus metabólitos aumentaram proporcionalmente com as dosagens de ácido vacênico. No primeiro experimento, a dose de $2 \%$ de ácido vacênico alcançou um plateau na produção de CLA. Os autores utilizaram esta mesma dosagem no segundo experimento para verificar sua eficácia no bloqueamento de lesões malignas na glândula mamária de ratas. A proliferação dos "terminal end buds" (TEBs), no epitélio mamário, foi utilizada como indicador de tumores após 6 semanas de administração do carcinogênico. $O$ tratamento com ácido vacênico reduziu o número total destas lesões malignas em $50 \%$. Os autores concluíram que a resposta anticarcinogênica do ácido vacênico foi mediada pela conversão endógena de CLA via SCD.

Ip et al. (1999a) realizaram um estudo para verificar se a gordura do leite de vacas enriquecida com CLA possuía a mesma atividade biológica da mistura de CLA. Para este fim, os autores utilizaram ratas Sprague-Dawley de 21 dias e verificaram que a suplementação da dieta dos animais durante o período da puberdade com esta gordura, reduziu em $30 \%$ a proliferação das células TEB e inibiu a progressão do tumor mamário em 53\%. Os animais consumindo esta gordura também acumularam mais CLA cis-9, 
trans-11 na glândula mamária e outros tecidos (quatro a seis vezes mais) que os animais consumindo CLA como ácido graxo livre. Isto sugere que a presença de ácido vacênico livre, na gordura, pode ter servido como um precursor para a síntese endógena de CLA via reação da SCD. Corroborando com estes dados, Thompson et al. (1997) verificaram que a suplementação de CLA na dieta de ratas durante a puberdade reduziu em $30 \%$ a síntese de DNA nos TEBs e ductos lóbulo alveolares.

Uma possível explicação pela qual o CLA inibe a carcinogênese nas células mamárias foi descrita em um trabalho realizado por Ip et al (1999b). O CLA inibiu o crescimento e diferenciação das células epiteliais normais de glândula mamária, em culturas primárias, através de uma redução da síntese de DNA e estímulo da apoptose. Estas observações demonstram que o CLA pode agir diretamente na prevenção do câncer através da inibição do crescimento e estímulo da apoptose nestas células. Neste mesmo trabalho, foram utilizadas duas formas de CLA; uma mistura de isômeros ou o isômero puro do CLA cis-9, trans-11. Entretanto, os autores demonstraram que ambas as formas do CLA inibiram o crescimento das células epiteliais mamárias, porém a mistura foi mais potente nesta inibição. Isto sugere que o CLA como mistura continha um outro isômero com atividade anticarcinogênica tão alta quanto o isômero cis-9, trans-11 e que a união dos dois isômeros potencializou a ação do CLA.

Apesar dos resultados citados acima, o mecanismo exato da ação anticarcinogênica do CLA, ainda não é bem compreendido. Pesquisas in vivo (Ip, et al, 1991) haviam indicado que a ação anticarcinogênica do CLA era atribuída às suas propriedades antioxidantes. Posteriormente, Zhang \& Chen, (1997) observaram que o CLA não age como um antioxidante e, sim, acelerando a peroxidação lipídica. Entretanto, Igarashi \& Miyazawa (2001) trabalhando com linhagens celulares humanas de hepatoma (HepG2) verificaram que a proliferação celular foi inibida na presença de 10-40 $\mu \mathrm{M}$ de CLA, quando comparado às células controle, após 72 horas. Para medir se o efeito inibitório do CLA no crescimento celular era originado da peroxidação lipídica as células foram incubadas em um meio que continha antioxidantes como $\alpha$ - tocoferol e BHT. Entretanto, a adição destes antioxidantes, no meio com CLA, não reverteram a inibição do crescimento celular induzido pelo CLA. Os autores sugerem que o efeito 
inibitório do crescimento nestas células é causado por mudanças não conhecidas no metabolismo dos ácidos graxos, pois, o conteúdo de lipídios e ácidos graxos claramente aumentou nas células suplementadas com CLA, comparadas às células controle.

\subsubsection{CLA e síntese de gordura na glândula mamária}

A depressão da gordura no leite (DGL) a qual ocorre sob certas condições, tais como dietas com elevadas quantidades de concentrado, representam uma situação extrema onde a síntese de gordura no leite pode ser reduzida em 50\% ou mais (Griinari, et al., 1997). Adicionalmente, várias outras manipulações dietéticas incluindo gorduras ativas no rúmen, tamanho reduzido de partículas, baixo teor de volumoso e uso de ionóforos resultam em vários graus de redução da produção de gordura do leite (Suton, 1989; Van Soest, 1994). Os mecanismos envolvidos na DGL não estão completamente elucidados, porém algumas teorias têm sido propostas. Estas teorias podem ser sumarizadas em duas categorias: as quais consideram que a depressão da gordura é uma conseqüência da diminuição no suprimento de precursores de lipídios para a glândula mamária e teorias que atribuem a DGL a uma inibição direta na glândula mamária de uma ou mais etapas na síntese de gordura do leite. A teoria mais tradicionalmente aceita envolve a redução nos precursores de lipídios como causa da DGL e foi denominada de teoria glicogênica/insulínica. De acordo com esta teoria, um aumento na ingestão de concentrado, aumentaria a concentração de insulina circulante, a qual aumentaria a partição de nutrientes para deposição no tecido adiposo, diminuindo a quantidade de precursores para síntese de gordura na glândula mamária, que não seria responsiva à insulina (Van Soest, 1994). Entretanto, estudos não observaram a DGL quando os níveis de insulina circulante foram cronicamente elevados (McGuire et al. 1995).

Em relação às teorias envolvendo uma inibição direta na glândula mamária, componentes os quais poderiam ser derivados da dieta ou produzido por fermentação ruminal, ou mesmo pelo metabolismo animal, têm sido sugerido como possíveis agentes capazes de agir em algum nível das rotas bioquímicas da síntese de gordura. Ação direta dos ácidos graxos trans na DGL foram propostas inicialmente por Davis \& Brown 
(1970). Pennington \& Davis (1975) também associaram os trans C18:1, produzidos pela biohidrogenação parcial dos ácidos graxos poliinsaturados, com DGL. Gaynor et al. (1995) estudaram as duas teorias propostas na redução da síntese de gordura do leite. Estes autores alimentaram vacas Holandesas com dois tipos de dietas denominadas: controle ( $40 \%$ de concentrado e $60 \%$ de forragem) e dieta rica em concentrado (80\% concentrado e $20 \%$ forragem) e os animais foram divididos em dois grupos, aqueles que apresentavam uma ou mais unidades na depressão de gordura foram classificados como responsivos e aqueles restantes foram classificados como não responsivos. Os autores observaram que quando os animais responsivos mudavam de uma dieta controle para uma dieta rica em concentrado, estes apresentaram uma porcentagem maior de ácidos graxos trans no leite, maior produção de leite, redução na porcentagem de gordura e uma tendência a aumento na quantidade de proteína no leite $(\mathrm{P}=0,06)$, dentre outras alterações nos parâmetros metabólicos observados. A ausência de uma maior concentração de glicose e insulina, no sangue, das vacas com maior queda na porcentagem de gordura no leite (responsivas) quando comparadas às vacas não responsivas foram contra a teoria glicogênica/insulínica para explicar por completo a depressão da gordura no leite, induzida pela dieta. Entretanto, elevadas concentrações de ácidos graxos trans C18:1 na gordura do leite dos animais responsivos, suportaram a teoria do efeito dos ácidos graxos trans na depressão da gordura do leite. Além disto, uma redução na concentração de ácidos graxos C14:0, C16:0 e C18:0 nos animais recebendo dietas ricas em concentrado quando comparada aos animais recebendo dieta controle suportam a hipótese de um efeito dos ácidos graxos trans na redução tanto da síntese de novo quanto na utilização dos ácidos graxos pré formados no leite.

Griinari et al. (1998) examinaram os efeitos da suplementação de dietas com gorduras insaturadas e alteração da fermentação ruminal na DGL. Os autores demonstraram uma diferença entre os tratamentos quanto aos isômeros posicionais trans C18:1. A adição de gordura insaturada e grande quantidade de forragem resultou no aumento do conteúdo de C18:1 trans-11 no leite e não alterou a porcentagem de gordura do leite, mas a adição em dietas ricas em concentrado aumentou o conteúdo de trans-10 e diminuiu a porcentagem de gordura no leite em $30 \%$, quando comparado ao controle. 
Estes dados sugerem que isômeros trans específicos ou metabólitos estão mais relacionados com mudanças na síntese de gordura do leite do que os trans C18:1 totais. Além do mais, a adição de gordura insaturada na dieta diminuiu a concentração de ácidos graxos derivados da síntese de novo (C4:0 ao C14:0) e aumentou a concentração dos ácidos graxos pré-sintetizados no leite (parte do C16:0 e C18:0). Embora a DGL ocorrida nas dietas com baixa fibra envolva sempre uma redução na produção de ambos ácidos graxos; sintetizados de novo e pré-formados.

Em outro trabalho, Griinari et al. (1999) encontraram uma relação linear entre a concentração de C18:1 trans-10 e CLA trans-10, cis-12 na gordura do leite. As concentrações de CLA trans-10, cis-12 no leite variaram entre 0,02 e $0,2 \%$ do total de ácidos graxos, do leite, e representaram menos que 5\% dos níveis de CLA cis-9, trans11, o isômero de CLA predominante na gordura do leite. Trabalho subsequente deste grupo, demonstrou que é o isômero trans-10, cis-12 que diminui a gordura do leite, e não o isômero cis-9, trans-11 (Baumgart et al., 2000a). Neste trabalho, infusões no abomaso de vacas Holandesas foram realizadas durante 4 dias e os tratamentos compreendiam o isômero de CLA cis-9, trans-11 e, em um segundo tratamento, o trans-10, cis-12. O tratamento com o isômero trans-10, cis-12 reduziu em $42 \%$ e $44 \%$ a porcentagem e a produção de gordura no leite, respectivamente. A composição de ácidos graxos no leite revelou que o isômero de CLA trans-10, cis-12 reduziu preferencialmente os ácidos graxos sintetizados de novo. Um aumento na proporção de C14:0/ C14:1, C16:0/ C16:1 e C18:0/ C18:1 indicou que este isômero inibiu a atividade da SCD.

Peterson et al. (2002) demonstraram, recentemente, através da união dos dados de diversos trabalhos que, embora o isômero trans-10, cis-12 compreenda apenas uma pequena proporção da gordura total do leite, uma relação quadrática existe entre redução na porcentagem de gordura do leite e aumento do conteúdo de trans-10, cis-12 nesta gordura $\left(\mathrm{R}^{2}=0,96\right)$ (dados mostrados na Figura 3a) e também entre redução na porcentagem de gordura do leite e aumento das dosagens de trans-10, cis-12 infundidas $\left(\mathrm{R}^{2}=0,99\right)$ (dados mostrados na Figura 3b). Efeitos na composição de ácidos graxos do leite fornecem informações do mecanismo pelo qual a síntese de gordura do leite é inibida. Em ruminantes, ácidos graxos com menos de 16 carbonos são sintetizados de 
novo, enquanto parte dos ácidos graxos com mais de 16 carbonos e os ácidos graxos com 18 ou mais carbono surgem do consumo de ácidos graxos circulantes. Em outro experimento (Perfield et al., 2002), houve um efeito similar do CLA trans-10 cis-12 tanto nos ácidos graxos sintetizados de novo como nos ácidos graxos pré-formados. Estes autores puderam, então, concluir que mudanças na composição de ácidos graxos do leite, não estão relacionadas somente com a inibição da síntese de ácidos graxos de novo ou apenas com a inibição da disponibilização e utilização dos ácidos graxos préformados, mas sim envolvem um mecanismo que reduz as duas vias metabólicas. 


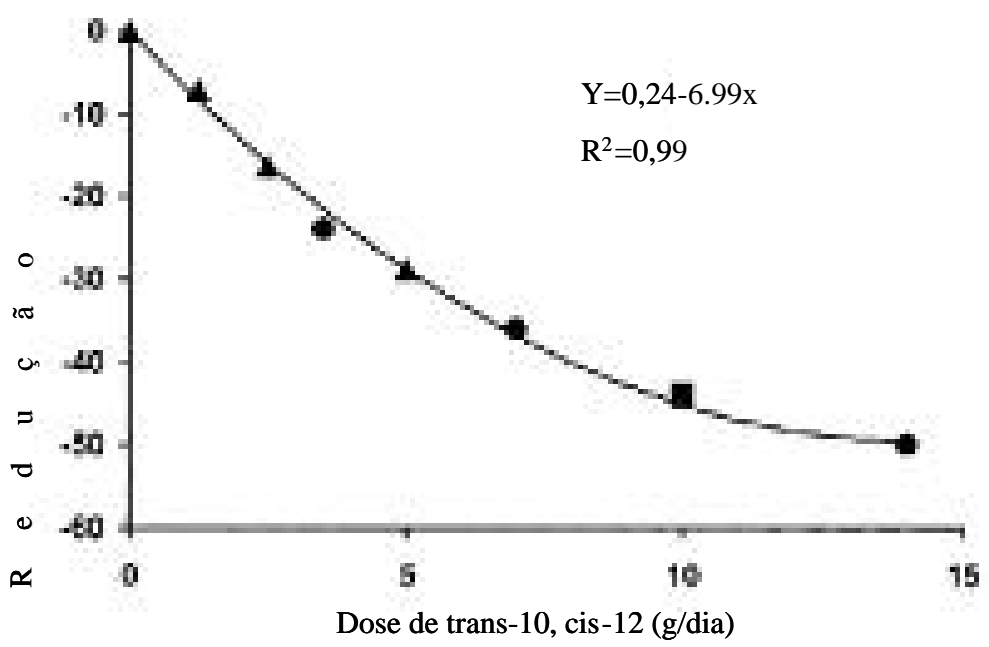

Figura 3a - Relação entre a diminuição na produção da gordura do leite e doses de CLA trans-10, cis-12 infundidos no abomaso de vacas lactantes.

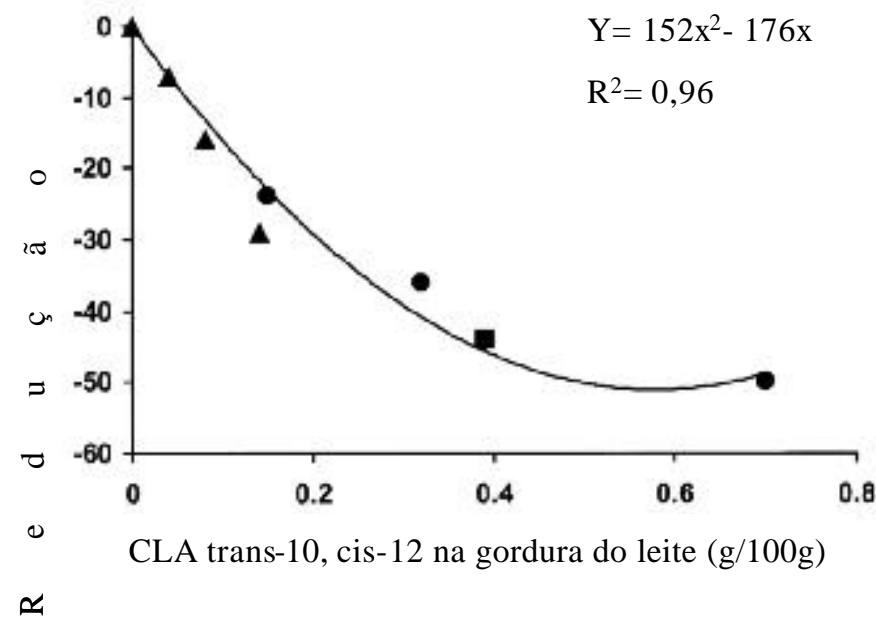

Figura 3b - Relação entre a diminuição na produção da gordura do leite e o conteúdo de CLA trans-10, cis-12 na gordura do leite.

Adaptado de Peterson et al. (2002) 
Chouinard et al. (1999a) infundiram no abomaso de vacas em lactação uma mistura de isômeros de CLA e verificaram que todos os isômeros contidos na mistura (cis/trans 8,10; cis/trans 9,11; cis/trans 10,12 e cis/trans 11,13) foram transferidos para o leite dos animais de uma maneira dose dependente. A menor eficiência de transferência (10\%) foi para o isômero cis/trans 10,12. Sendo a eficiência dos outros isômeros por volta de $20 \%$. Neste trabalho, ocorreu uma redução na gordura do leite (em média de 52-55\%) e a análise do perfil de ácidos graxos no leite demonstrou uma redução na síntese de novo e na dessaturação dos ácidos graxos. Baumgard et al. (2001) verificaram que doses acima de 7 gramas/dia de trans-10, cis-12 infundidas no abomaso de vacas em lactação, levou a uma redução significativa nos ácidos graxos sintetizados de novo. Mudanças na composição de ácidos graxos no leite destes animais demonstraram que a atividade da SCD também foi inibida. Corroborando estes dados, Loor \& Herbein (1998) e Giesy et al. (2002) também verificaram que isômeros de CLA ou o CLA na forma de sais de cálcio foram capazes de reduzir em 34\% a gordura do leite devido principalmente a redução nos ácidos graxos de cadeia de 6 a 16 carbonos sugerindo uma potente inibição da síntese de novo na glândula mamária. Loor \& Herbein (1998) verificaram um aumento de dez vezes na concentração de CLA nos triglicerídios plasmático além de um aumento na concentração de CLA no leite. Os resultados sugerem que o conteúdo de CLA no leite reflete a quantidade de CLA disponível para absorção no intestino delgado.

Piperova et al. (2000) utilizaram dietas DGL para avaliar o efeito na atividade da ACC e FAS. Estes autores observaram uma redução na atividade destas enzimas de $61 \%$ e 44\% para a ACC e FAS, respectivamente. Além disso, uma redução na abundância do RNAm da ACC foi observada. Em acordo com a menor atividade, foi observada uma redução de $43 \%$ na gordura do leite destes animais, oriunda da redução da síntese de novo na glândula mamária. Conseqüentemente, os ácidos graxos sintetizados de novo foram reduzidos ( $27 \%$ na proporção e $60 \%$ na produção), onde os ácidos graxos trans tiveram um aumento de $1,9 \%$ para $15,6 \%$ no leite dos animais suplementados com a dieta DGL, reflexo predominante do aumento dos ácidos graxos trans-10 C18:1. Nesta dieta com DGL a concentração do isômero trans-10, cis-12 foi aumentado dez vezes. Os resultados são consistentes com o papel do CLA trans-10, cis-12 na depressão da gordura do leite 
reportados previamente por Baumgard et al. (2000a), mas mudanças observadas em outros ácidos graxos trans e isômeros do CLA também podem ser importantes.

Para estudar os mecanismos pelos quais o CLA trans-10, cis-12 reduz a gordura do leite, Baumgard et al. (2002b), com infusão do isômero trans-10, cis-12 no abomaso de vacas lactantes durante 5 dias, verificaram uma redução de $48 \%$ na quantidade de gordura no leite e um aumento de trans-10, cis-12 no leite dos animais recebendo CLA de 0,1 para 4,9 mg/g quando comparados ao controle. Reduções no conteúdo dos ácidos graxos C4:0 a C16:0, no leite, tiveram uma contribuição de $63 \%$ para a redução da gordura. Corroborando estes dados, os autores analisaram a capacidade lipogênica dos tecidos e verificaram uma redução de $82 \%$ nesta capacidade quando os animais receberam CLA trans-10, cis-12. A infusão de CLA também modificou a abundância do RNAm de enzimas envolvidas na lipogênese, indicada pela redução de 40\%, 39\% e 48\% da FAS, ACC e SCD, respectivamente. Adicionalmente, a expressão da lipoproteína lipase (LPL) foi reduzida em $48 \%$ e da proteína ligadora de ácidos graxos também foi reduzida em 54\%. A expressão da glicerol fosfato acil transferase e acil glicerol fosfato acil transferase envolvidas na síntese de triglicerídios foram reduzidas em 40\%. Concluindo-se, estes dados demonstram que os mecanismos pelos quais o CLA trans-10, cis-12 inibe a síntese de gordura no leite incluem: diminuição da expressão de genes que codificam enzimas envolvidas no consumo de ácidos graxos circulantes e transporte, síntese de novo de ácidos graxos, dessaturação de ácidos graxos e síntese de triglicerídios.

Em trabalho recente conduzido por este mesmo grupo (Baumgard et al., 2002a), uma série de experimentos foram realizados para elucidar os efeitos do CLA no metabolismo lipídico e controle homeostático, em vacas lactantes. Três experimentos foram conduzidos, ao longo deles reduções de $25 \%$ a $50 \%$ foram alcançadas na gordura do leite, o equivalente de $6 \%$ a $11 \%$ da energia líquida. Entretanto, os efeitos foram específicos para a gordura do leite, sendo que nenhuma alteração foi observada na ingestão alimentar e produção de leite ou produção de proteína. Os níveis de metabólitos circulantes como glicose, insulina ou leptina não apresentaram alterações com as dosagens de CLA. As concentrações basais de ácidos graxos livres também não foram afetadas, mas a resposta lipolítica à epinefrina foi reduzida em dois tratamentos quando as vacas receberam CLA 
trans-10, cis-12, sendo que no último tratamento não houve resposta. Resumindo, os efeitos do CLA trans-10, cis-12 parecem ser muito mais pronunciado no tecido da glândula mamária, resultantes da síntese de gordura reduzida. Os efeitos do CLA na resposta do tecido adiposo aos sinais homeostáticos reguladores da lipólise (epinefrina) não permitiram aos autores concluírem que o CLA poderia estar agindo desta forma. Entretanto, alterações de fatores associados à homeostase da glicose poderiam estar envolvidos com mecanismos onde o CLA reduziria a síntese de ácidos graxos e deposição de gordura corporal. Porém, neste estudo, o CLA trans-10, cis-12 não alterou a concentração plasmática basal destes fatores. 


\section{MATERIAL E MÉTODOS}

\subsection{Modelo animal}

Foram utilizadas 16 ratas da raça Wistar, do Laboratório de Nutrição e Crescimento Animal - Departamento de Zootecnia ESALQ-USP, com peso inicial médio de 260 gramas. As fêmeas receberam ração suplementada com CLA do dia da parição até o pico de lactação (15 dias post partum).

As fêmeas foram mantidas, em gaiolas individuais, em uma sala isolada, com temperatura controlada entre $23-25^{\circ} \mathrm{C}$ e fotoperíodo de 12 horas (luz entre 06:00 e 18:00 horas) durante todo o período experimental.

\subsection{Dieta}

Os animais foram alimentados com uma dieta comercial da Purina (Labina Ração para animais de laboratório) na forma de peletes até no máximo 7 dias pré-parto. A partir desta data, as fêmeas receberam a mesma ração, mas na forma farelada para um período de adaptação (Figura 4). A dieta atendia a todas exigências nutricionais recomendadas pelo NRC (1978).

Os animais foram separados em dois grupos a partir do parto e receberam do dia 0 (parto) ao $15^{\circ}$ dia os seguintes tratamentos:

1) Controle: dietas contendo a seguinte composição bromatológica: 90,69\% de MS; 25,37\% de PB; 5,05\% de FB; 3,86\% de EE; 8,29\% de MM; 1,48\% de Ca e $0,83 \%$ de $\mathrm{P}$. 
2) 2,5\% de CLA-60 na dieta: Contendo a seguinte composição bromatológica: 25,37\% de PB; $5,05 \%$ de FB; $5,86 \%$ de EE; $8,30 \%$ de MM; $1,53 \%$ de Ca e $0,83 \%$ de $\mathrm{P}$, com base na matéria seca. Esta ração continha $0,41 \%$ na matéria seca total do isômero trans- 10 , cis- 12 .

O CLA-60 contém 60\% de isômeros de CLA na seguinte proporção: $24 \%$ cis/trans 9,$11 ; 35 \%$ cis/trans 10,$12 ; 15 \%$ cis/trans 8,$10 ; 17 \%$ trans 11 , trans13 e $9 \%$ outros. Portanto, considerando-se que os sais de CLA-60 produzidos para este experimento (Church \& Dwight, Princeton, NJ) continham 20\% de cinzas e 80\% de ácidos graxos houve um consumo equivalente a $407 \mathrm{mg} / \mathrm{kg}$ de peso vivo do isômero cis/trans 10,12 .

No último dia do período experimental, os animais foram ordenhados e, em seguida, sacrificados para retirada dos tecidos (Figura 4).

A escolha da dose utilizada neste experimento foi baseada nos resultados obtidos previamente por DeLany et al. (1999), no qual se observa que o peso dos tecidos adiposos mesentérico, epididimal e inguinal de ratos diminuem com a ingestão de $0,41 \%$ da matéria seca total de isômero trans-10, cis-12. Esta idéia de que esta quantidade do isômero, na dieta, devia ser adequada para se testar as hipóteses foi reforçada pelos resultados de Baumgard et al. (2000a), que observaram uma diminuição de 36\% na porcentagem de gordura no leite nas vacas que receberam por infusão, no abomaso, $0,27 \%$ do isômero trans- 10 , cis- 12 .

Observa-se através da composição bromatológica da dieta que a energia foi diferente nas duas dietas experimentais. Porém, foi reportado pelo NCR (1978) que dietas contendo até $18 \%$ de gordura não afetam o consumo e também não afetam parâmetros reprodutivos de roedores. É importante destacar que esta quantidade do isômero trans-10, cis-12 presente na dieta não é considerada como um nível tóxico para ratos. Trabalhos anteriores, Scimeca (1998) observou que uma dieta contendo 0,58\% do isômero trans-10, cis-12 não resultou em nenhum prejuízo para a saúde destes animais. 


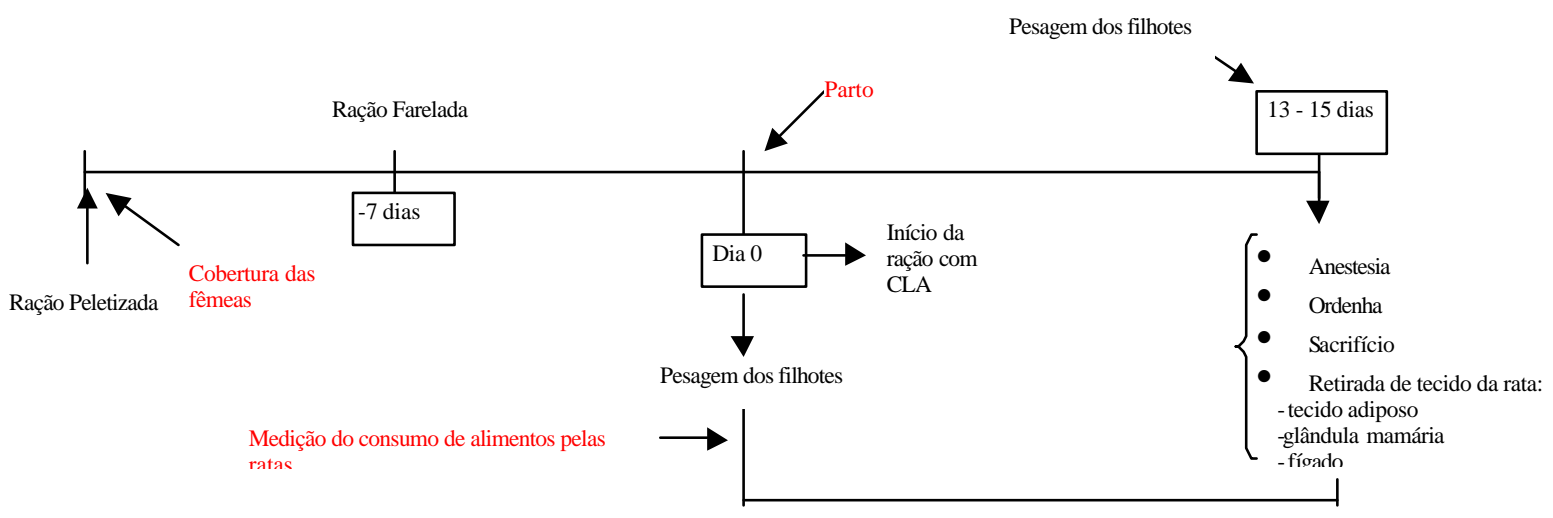

Figura 4 - Representação esquemática do plano de trabalho realizado no experimento.

\subsection{Consumo de Alimento}

Durante todo o período experimental, do primeiro dia do parto até o $15^{\circ}$ dia, a ração era trocada diariamente entre 8 e 9 horas da manhã e as sobras eram pesadas. Controlando-se as quantidades oferecidas e as sobras, foi possível estabelecer a ingestão diária individual.

\subsection{Ganho de peso dos animais}

O ganho de peso das fêmeas e da prole foi acompanhado desde o dia do nascimento ao último dia do experimento. A prole era retirada das fêmeas nos dias previamente estipulados de pesagem, no período da manhã (para se evitar possíveis alterações diurnas nos pesos das ninhadas) e imediatamente pesados. As pesagens foram realizadas no dia do nascimento (0) e aos 4, 8, 12 e 15 dias de idade, em toda prole de cada fêmea. Nestes mesmos dias, o acompanhamento do peso das fêmeas também foi realizado. 


\subsection{Coleta de material}

Durante o $15^{\circ}$ dia de lactação, as ratas foram separadas da prole 4 horas antes da retirada da amostra de leite. Após a realização da ordenha, os animais foram abatidos para retirada de sangue da aorta abdominal sobre leve efeito anestésico de pentobarbital sódico (48 mg/kg) e este sangue foi coletado em tubos "Vacuntainer" com EDTA. As amostras foram, então, resfriadas em isopor com gelo imediatamente após a coleta e, em seguida centrifugadas a 5000xg. O plasma obtido foi então transferido para microtubos, e armazenado a $-20^{\circ} \mathrm{C}$ para análises posteriores.

Após a coleta de sangue, amostras de tecido adiposo omental, tecido da glândula mamária e fígado foram retiradas e imediatamente estocadas a $-80^{\circ} \mathrm{C}$.

Amostras de leite foram estocadas a $-80^{\circ} \mathrm{C}$ em microtubos para uma posterior realização da análise de composição do leite quanto ao percentual de gordura e perfil de ácidos graxos, incluindo isômeros de posições e estereoisômeros.

\subsubsection{Parâmetros Plasmáticos}

O plasma congelado foi utilizado para análise dos seguintes parâmetros: ácidos graxos livres (AGNE), triglicerídeos (TGA) e colesterol total. Para as análises de AGNE utilizou-se um método enzimático-colorimétrico (NEFA C, Wako Chemicals). A quantidade de AGNE presente na amostra pôde ser determinada através da medida de densidade ótica a 550nm, em espectrofotômetro. As análises de TGA e colesterol total também foram realizadas com ensaios enzimáticos colorimétricos (Colesterol, Bio

Diagnóstica e Triglicerídeos, Bio Diagnóstica) com leituras realizadas em espectrofotômetro.

\subsubsection{Avaliação da composição do leite}

Os lipídeos totais do leite foram extraídos como descrito previamente por Hara \& Radim (1978) com algumas modificações, devido ao volume de leite reduzido. Para a 
extração de gordura, as amostras de leite, foram congeladas após serem liofilizadas, e armazenadas em tubos lacrados e insuflados com $\mathrm{N}_{2}$. Desta amostra, foram retirados 1 grama para a extração de gordura. Em um tubo de extração foram adicionados $18 \mathrm{~mL}$ de uma mistura Hexano:Isopropanol (3:2), agitadas vigorosamente por 1 minuto e, em seguida, adicionou-se $9 \mathrm{~mL}$ de uma solução de sulfato (1g de sulfato de sódio/ $15 \mathrm{~mL}$ de $\mathrm{H}_{2} \mathrm{O}$ ). Seguindo-se de agitação vigorosa por 1 minuto e descanso até a separação em duas fases. A fase superior foi cuidadosamente extraída e transferida para um tubo com $1 \mathrm{~g}$ de sulfato de sódio e mantida em repouso por 30 minutos. Após este período, a camada superior (a qual continha Hexano e lipídeos dissolvidos) foi armazenada em um tubo limpo e secada sobre $\mathrm{N}_{2}$ até que todo solvente evaporasse.

Através de uma equação de subtração, pôde-se determinar a quantidade de lipídeos totais do leite dos animais. A metilação foi feita através do uso de uma solução metanólica de metóxido de sódio de acordo com Christie (1982) e o perfil de ácidos graxos foi determinado através de cromatografia gasosa utilizando-se uma coluna capilar de sílica fundida, SP-2560 (100m x 0,25 mm x 0,2mm; Supelco) e detector de ionização de chama (FID). Foi utilizado, também, um programa de gradiente de temperatura, no qual o tempo total da corrida foi de 70 minutos e a temperatura do injetor foi $250^{\circ} \mathrm{C}$, e o detetor $300^{\circ} \mathrm{C}$. A injeção foi no modo "split", com relação 21:1. O gás de arraste foi o Hélio com fluxo de 40 $\mathrm{mL} /$ minuto e 18 psi de pressão na cabeça da coluna.

O perfil de ácidos graxos é expresso em porcentagem do total de ácidos graxos. Como padrão, foi usado o CRM-164 (Commission of the European Communities, Comunity Bureau of Reference, Bruxelas, Bélgica), que tem valores certificados para 11 ácidos graxos, usados para estabelecer os fatores de correção, para cada um dos ácidos graxos certificados que foram usados para transformar o pico em porcentagem em área para peso (mg/g ácidos graxos totais). 


\subsubsection{Ensaio das atividades enzimáticas}

Amostras de glândula mamária, fígado e tecido adiposo estocadas a $-80^{\circ} \mathrm{C}$ foram utilizadas para o ensaio da atividade da ácido graxo sintase (FAS), 6-fosfogluconato desidrogenase (6PGDH), glicose 6-fosfato desidrogenase (G6PDH) e NADP-malato desidrogenase.

\subsubsection{Preparação das amostras}

Amostras de 1 grama dos tecidos obtidos, como descrito anteriormente, foram adicionadas ao tampão de homogeneização $(0,15 \mathrm{M} \mathrm{KCl}, 50 \mathrm{mM}$ de Tris Base e Tris $\mathrm{HCl}$, $1 \mathrm{mM}$ de Glutationa e $1 \mathrm{mM}$ de EDTA, $\mathrm{pH} 7,4)$, homogeneizadas rapidamente em "politron”, seguindo-se centrifugação a $4^{\circ} \mathrm{C}, 2000 x g$ por 15 minutos. Seguindo-se de nova centrifugação, por $30 \mathrm{~min} ., 4^{\circ} \mathrm{C}, 27000 x g$. A camada superior de gordura foi descartada e o infranadante retirado. Uma alíquota do infranadante foi armazenada para posterior medição do teor de proteína.

\subsubsection{Ensaio da atividade enzimática da FAS}

O ensaio da atividade da FAS foi realizado de acordo com Ingle et al. (1973). A

atividade foi medida espectrofotometricamente, observando-se o desaparecimento de NADPH na reação de síntese de gordura a partir de acetil Co-A e malonil Co-A, na presença dos cofatores e do infranadante do homogenato. O monitoramento do NADPH foi feito a $340 \mathrm{~nm}$.

\subsubsection{Ensaio da atividade enzimática da G6PDH e 6PGDH}

$\mathrm{O}$ ensaio da atividade das enzimas G6PDH e 6PGDH foi feito de acordo com Glock \& Mc Lean (1953). 
A atividade da glicose-6 fosfato desidrogenase foi medida espectrofotometricamente, na presença dos cofatores e do infranadante do homogenato. Monitorou-se a transformação de NADP em NADPH com a atividade de ambas as enzimas medidas conjuntamente, subtraindo-se a atividade observada para a 6fosfogluconato desidrogenase sozinha. A atividade da 6- fosfogluconato desidrogenase foi realizada diretamente e com o mesmo protocolo.O monitoramento do NADPH foi feito a $340 \mathrm{~nm}$.

\subsubsection{Ensaio da atividade enzimática da NADP-malato desidrogenase}

O ensaio da atividade da enzima NADP-malato desidrogenase foi realizada de acordo com metodologia descrita por Mellemberger et al. (1973), medida sob espectofotômetro acoplando-se a formação de piruvato à formação de NADPH e monitorada a $340 \mathrm{~nm}$.

\subsubsection{Teor de proteína}

A atividade das enzimas foi expressa em nanomoles de substrato incorporado ou liberado por miligrama de proteína. Assim, o teor de proteína no homogenato foi observado para se evitarem possíveis efeitos de diferentes quantidades de tecido ou da eficiência dos processos de homogeneização e ensaio dos tecidos.

A concentração de proteína solúvel nos infranadantes foi determinada com Reagente Biureto (Gornall et al, 1949) e as atividades expressas em nmoles/min/mg de proteína.

\subsection{Análise estatística}

Para os dados de consumo e ganho de peso dos animais foram realizadas análises de variância utilizando-se PROC MIXED do SAS (2000). Para os dados de parâmetro plasmático, leite e atividades enzimáticas foram realizadas análises de variância utilizando-se o PROC GLM do SAS (2000). 
Os efeitos foram considerados significativos quando $\mathrm{P}<0,05$. 


\section{RESULTADOS E DISCUSSÃO}

\subsection{Consumo de alimentos e Ganho de peso das fêmeas}

O consumo médio de cada tratamento durante o período experimental não apresentou diferença $(\mathrm{P}>0,10)$. Estes resultados são consistentes com trabalhos anteriores de Chin et al. (1994b) que verificaram que uma dosagem de 0,5\% de CLA na dieta de ratas durante a gestação não afetou o consumo dos animais suplementados. Do mesmo modo, a suplementação com CLA não afetou $(\mathrm{P}>0,10)$ o ganho de peso pósparto das fêmeas (Figura 5). 


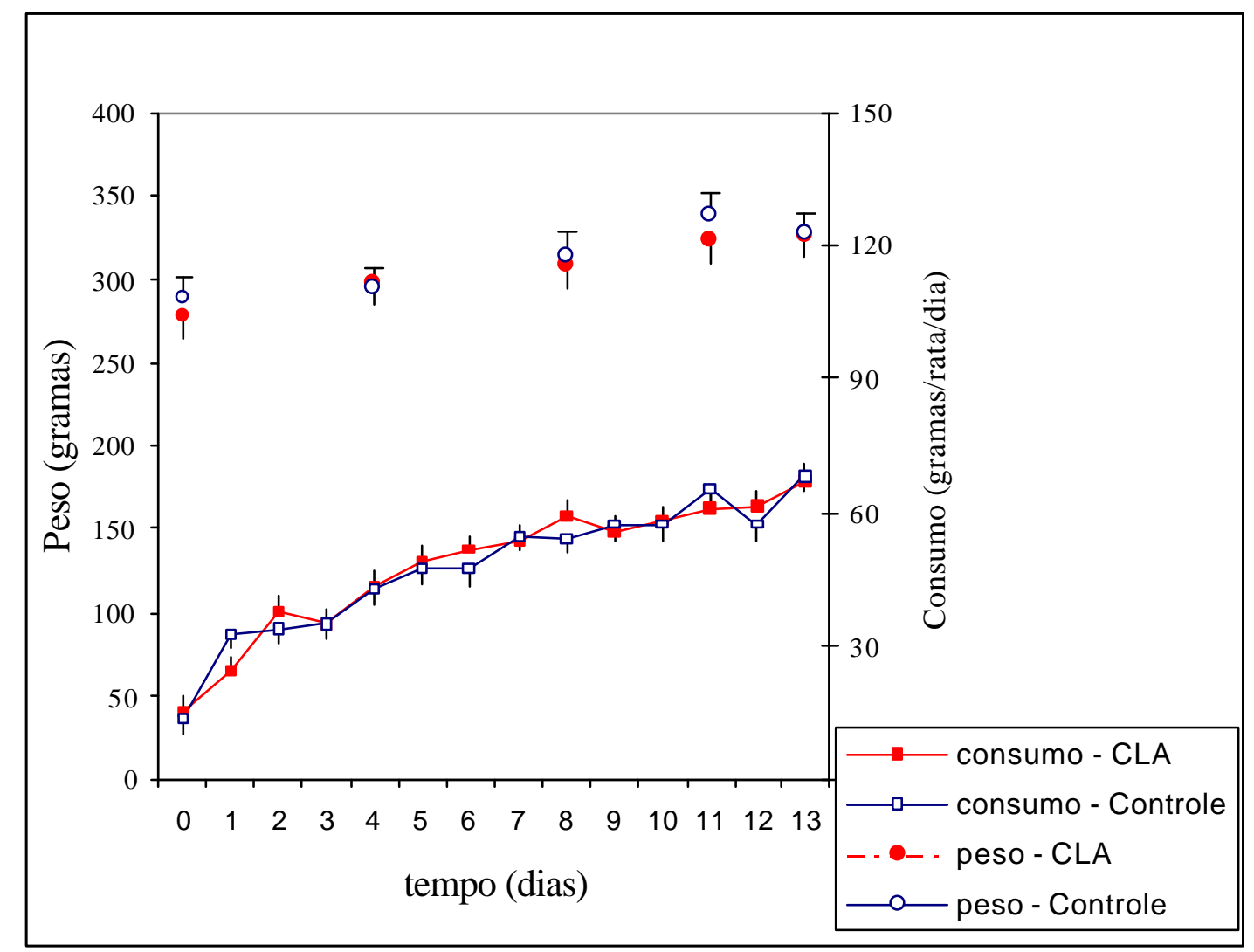

Figura 5 - Peso corporal (círculos) e consumo (quadrados) das ratas lactantes alimentadas por 15 dias com a dieta controle (símbolo vazado) ou CLA (símbolo cheio). O peso corporal $(n=8)$ e consumo $(n=8)$ foram analisados pelo teste $t(\mathrm{P}>0,10$ para ambas variáveis). Os pontos representam média \pm SE (erro padrão da média).

Existem trabalhos na literatura demonstrando efeito do CLA sobre consumo e peso, entretanto foram conduzidos com diferentes espécies animais em diferentes estágios fisiológicos. Park đ al. (1997) demonstraram que camundongos em crescimento recebendo $0,5 \%$ de CLA na dieta não alteravam o consumo de alimentos e nem o peso corporal, quando comparados ao tratamento controle. Por outro lado, DeLany et al. (1999) observaram que o CLA reduziu o ganho de peso dos camundongos sem afetar o consumo. Este efeito deveu-se possivelmente a uma redução nos depósitos de gordura 
corporal destes animais. No mesmo período, o grupo de Park e colaboradores (1999) estudou o efeito do isômero trans-10, cis-12 na composição corporal de camundongos na fase de crescimento. Os estudos demonstraram que este isômero é o responsável pela mudança na composição corporal dos animais, com uma significante redução observada no ganho de peso, no consumo e na porcentagem de gordura corporal. Os autores concluem que, possivelmente, o CLA agiu através de uma ação no metabolismo lipídico (aumento da oxidação dos ácidos graxos nos adipócitos e músculo esquelético). Sabe-se porém que estes animais estavam em fase de crescimento, depositando mais lipídios do que oxidando-os. Desta forma, a conhecida ação do CLA na atividade das enzimas LPL, FAS e SCD foi suficiente para reduzir o ganho da gordura corporal destes e também mudar sua composição corporal. Porém, em relação às ratas lactantes, uma vez que estes animais não estão depositando quantidades apreciáveis de lipídios no tecido adiposo, uma possível inibição da síntese de lipídeos não levaria a uma diferença significativa no peso ou no consumo do animal.

Corroborando os resultados encontrados, Poulos et al. (2001) verificaram que dosagens de 0,5\% de CLA não mudaram o ganho de peso e o consumo das ratas suplementadas durante a gestação e lactação ou somente durante a lactação, quando comparado ao tratamento controle.

\subsection{Peso da Progênie}

Na figura 6, estão apresentados os pesos da prole amamentada por fêmeas suplementadas com CLA (prole-CLA) e por fêmeas suplementadas com dieta controle (prole-controle). Pôde-se observar que o peso da prole se torna diferente a partir do $8^{0}$ dia de pesagem $(\mathrm{P}=0,02)$ e permanece maior para a prole-controle até o final do experimento. Para a prole-CLA, observou-se uma redução de 13\%, $19 \%$ e $21 \%$ da massa em relação ao controle, nos dias 8, 12 e 15, respectivamente. A partir destes dados, é provável que a menor densidade energética presente no leite das ratas recebendo CLA foi responsável por uma redução no ganho de peso da prole. 
Os resultados observados na figura 6 parecem indicar que a mistura de CLAs inibiu a síntese e secreção de gordura pelas células da glândula mamária de ratas, reduzindo assim o desenvolvimento da prole, provavelmente por deficiência energética. Os resultados obtidos por Baumgard et al. (2000a) demonstram que o isômero trans-10, cis-12 está envolvido na depressão da gordura do leite em vacas. Outros trabalhos também identificaram o trans-10, cis-12 como isômero capaz de inibir as enzimas lipogênicas, portanto é provável que este isômero seja o responsável pela redução na gordura do leite das mães e pelos efeitos observados na figura 6. Yang et al. (2002), além de verificarem redução no teor de gordura do leite no $7^{\circ}$ dia de ratas recebendo CLA, observaram uma relação direta entre a quantidade dos isômeros de CLA consumida e as quantidade encontrada no leite das ratas, através de análises feitas por HPLC. Verificaram, também, redução nos ácidos graxos de cadeia C12:0 e C14:0 e um concomitante aumento nos de cadeia C18:0. Entretanto, estes autores não verificaram diferenças no ganho de peso da prole. Esta falta de efeito sobre o peso da ninhada pode ser função da raça das ratas (Sprague-Dawley) que teria grande quantidade de leite, mais que o suficiente para manter ganho de peso máximo da prole. Especula-se, à partir da análise conjunta dos dados deste experimento e dos resultados observados por Chin et al. (1994b) que, com ninhadas pequenas ou ratas com alta produção de leite, não há déficit energético, pois a progênie pode compensar o menor teor de energia consumindo mais leite. Sob estas condições é possível que um provável efeito anabólico do isômero cis-9, trans-11 se sobreporia ao efeito do isômero trans-10, cis-12. Isto suporta o aumento do peso da ninhada, observado por Chin et al. (1994b). Por isso, neste trabalho, tomou-se o cuidado de se estabelecer todas estas variáveis (número grande da prole, ratas de moderada produção leiteira). 


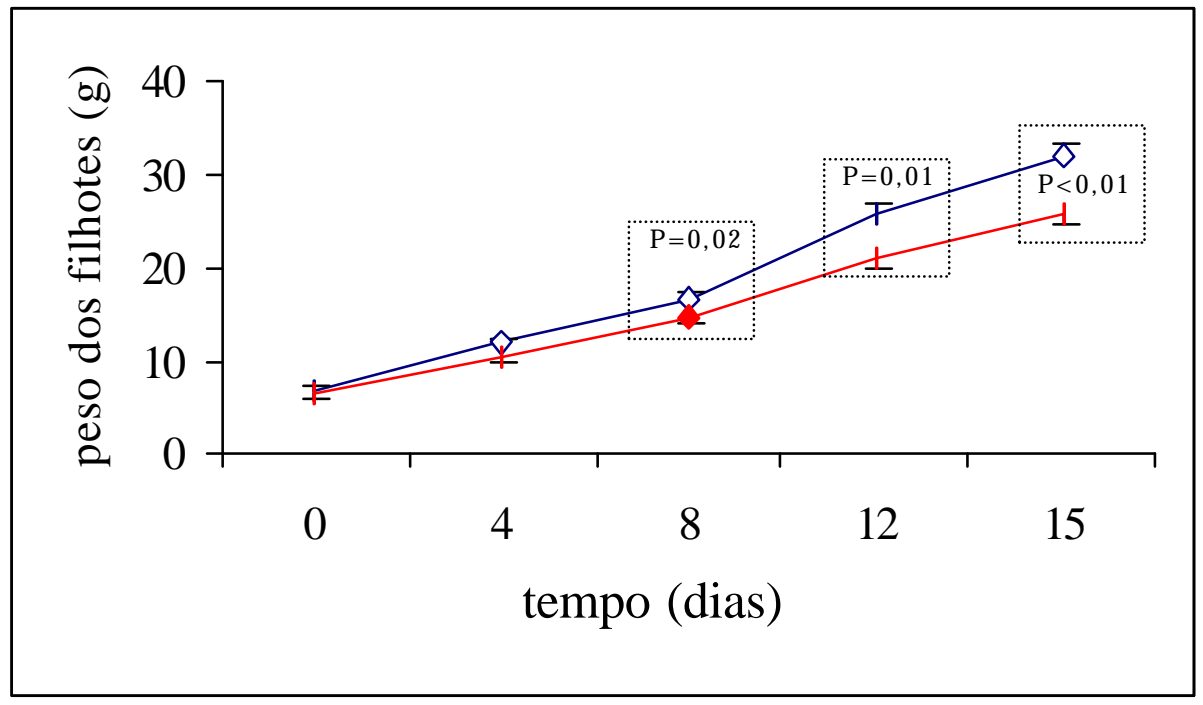

Figura 6 - Peso da prole de fêmeas alimentadas com dieta controle (vazado) e CLA (cheio) ao longo da lactação. Valores de $\mathrm{P}$ estão apresentados na figura. Tamanho médio das ninhadas $=11$.

Corroborando a hipótese do nosso trabalho, Bee (2000) suplementou com CLA um grupo de porcas Large White com dez filhotes cada, durante a gestação e lactação e observou que não houve uma diferença no ganho de peso corporal após desmama, da prole amamentada pelas fêmeas-CLA. Porém, as ninhadas não eram consideradas grandes e os animais utilizados são conhecidos por possuírem elevadas produções de leite. Provavelmente não foi possível estabelecer um déficit energético naquele trabalho e, conseqüentemente, evidenciar o efeito predominante do isômero trans-10, cis-12 observado nas ratas.

O presente trabalho verificou uma ação da suplementação do CLA na dieta maternal no ganho de peso da prole. Entretanto, trabalhos demonstraram que o efeito do CLA na redução da gordura corporal é, sob certas condições, menos pronunciado em ratos que em camundongos, onde nestes, foram verificadas reduções de 50\%-80\% na gordura corporal (Park et al., 1997; DeLany et al., 1999). Alguns autores (Rahman et al., 2001; Ohnuri et al., 2001), verificaram que as reduções nos depósitos de gordura corporal ocorrem devido a um aumento na beta oxidação no tecido adiposo e 
concomitante aumento na atividade da Carnitina Palmitoil-transferase (CPT). Além disso, Terpstra et al. (2002) verificaram que camundongos em crescimento além de perderem mais energia na forma de calor, perderam parte da energia ingerida através das excretas $(-26 \%)$. Esta redução na eficiência do uso de energia pode estar ligada às UCPs ou a uma maior atividade física, ou ainda a outros fatores.

\subsection{Parâmetros Plasmáticos}

Na tabela 1, estão apresentados os dados de ácidos graxos não esterificados (AGNE), triglicerídeos (TGA) e colesterol total (Colesterol).

Tabela 1. Concentrações plasmáticas de AGNE, Colestrol e TGA.

\begin{tabular}{cccc}
\hline & \multicolumn{2}{c}{ Tratamentos } & \\
Variáveis $^{1}$ & Controle & CLA & $\mathbf{P}^{2}$ \\
\hline $\begin{array}{c}\text { Ácido graxo não } \\
\text { esterificado }(\mu \mathrm{moles} / \mathrm{L})\end{array}$ & $505 \pm 38$ & $486 \pm 49$ & 0,76 \\
Colesterol $(\mathrm{mg} / \mathrm{dL})$ & $52 \pm 3$ & $50 \pm 5$ & 0,72 \\
Triglicerídios $(\mathrm{mg} / \mathrm{dL})$ & $102 \pm 16$ & $118 \pm 32$ & 0,66
\end{tabular}

${ }^{1}$ Os valores representam média \pm SE, $n=9$ parcelas/tratamento no $15^{\circ}$ dia de lactação.

${ }^{2}$ Probabilidade de diferença entre os tratamentos.

Os valores de AGNE não diferiram estatisticamente entre os tratamentos controle e CLA. As concentrações de AGNE circulantes são altamente correlacionadas com a velocidade de lipólise. Entretanto, estudos com infusões de CLA trans-10, cis-12 no abomaso, de vacas lactantes (Baumgard et al., 2000a; Baumgard et al 2000b), não mostraram efeito nos níveis plasmáticos de AGNE, embora uma dramática redução na 
produção de gordura tenha sido observada (25-50\%). Em relação aos animais em

crescimento, demonstrou-se que as concentrações plasmáticas de AGNE foram levemente elevadas em suínos e ratos alimentados com dietas suplementadas com CLA (Ostrowska et al., 1999; Azain et al., 2000). A menor concentração de gordura no leite das ratas recebendo CLA poderia sugerir uma menor mobilização, entretanto este efeito não foi observado pelas concentrações de AGNE. A ausência de diferença neste parâmetro também sugere que o CLA não deve alterar a velocidade da lipólise.

Para os outros parâmetros plasmáticos estudados (TGA e Colesterol) também não foram verificadas diferenças. Corroborando estes dados, Azain et al. (2000) não verificaram diferenças nestas variáveis em ratos suplementados com CLA, embora estes autores tenham observado uma redução na deposição de gordura e ganho de peso dos animais.

\subsection{Concentração de lipídeos totais no leite}

A tabela 3 apresenta os valores da concentração da gordura do leite nos dois tratamentos. A concentração da gordura no leite foi deprimida (-33\%) no tratamento CLA. Esta redução está de acordo com os efeitos esperados do isômero trans-10, cis-12 na depressão da gordura do leite observado em vacas (Baumgard et al, 2000a). A figura 11 mostra a relação quadrática entre o conteúdo de trans-10, cis-12 no leite e a correspondente redução na produção de gordura no leite $\left(\mathrm{R}^{2}=0,64\right)$. Esta relação quadrática também foi observada anteriormente para vacas (Medeiros et al., 2002). O isômero trans-10, cis-12 é um conhecido inibidor da síntese de gordura na glândula mamária de vacas, entretanto este efeito não havia sido observado no leite de ratas. Este efeito do isômero trans-10, cis-12 ocorreu provavelmente em maior proporção na síntese de novo dos ácidos graxos, uma vez que foi observada uma alteração no perfil de ácidos graxos produzidos por esta via. Consequientemente, esta redução no teor energético do leite, poderia explicar o menor crescimento da prole (Figura 6). Por outro lado, Chin et al. (1994b) verificaram que a adição de uma mistura de isômeros de CLA, na dieta de ratas lactantes, não foi suficiente para reduzir o crescimento da prole, sugerindo deste 
modo que, no trabalho destes autores, não houve redução na concentração de gordura no leite das ratas ou que, pode ter havido depressão da gordura do leite, mas como o tamanho da ninhada foi pequeno, a quantidade de leite produzido pelas ratas pode ter sido suficiente para evitar um "déficit" energético na alimentação da prole. Conforme já comentado um aumento no volume ingerido poderia compensar uma possível menor densidade energética.

O mecanismo específico através do qual o CLA altera o metabolismo lipídico ainda não é completamente conhecido. Um possível mecanismo pode envolver o aumento na lipólise e oxidação dos ácidos graxos. Entretanto, como a lipólise é intimamente relacionada com a concentração de AGNE circulante e não foi observada alteração na concentração de AGNE neste experimento (Tabela 1) e em outros (Baumgard et al. 2000a), sugere-se que o efeito principal do CLA não seja na lipólise. Outro possível mecanismo do CLA na redução da gordura seria através da redução da absorção dos ácidos graxos pré-formados. Uma redução na atividade da lipoproteína lípase estaria ligada a este efeito. Park et al. (1997) verificaram uma alteração na atividade desta enzima em cultura de $3 \mathrm{~T} 3$ pré-adipócitos incubados com CLA. A atividade desta enzima, não foi estudada neste trabalho, mas esperava-se que, se uma alteração na atividade da lipoproteína lipase estivesse ocorrendo neste estudo, uma redução na quantidade dos ácidos graxos pré-formados seria verificada. Uma redução neste grupo de ácidos graxos realmente pode ter ocorrido, mas a redução nos ácidos graxos formados pela via de novo foi mais pronunciada, o suficiente para explicar quase totalmente a redução de gordura.

Tabela 2. Porcentagem de gordura presente na matéria seca do leite.

\begin{tabular}{cccc}
\hline Tratamento & Controle $^{1}$ & CLA $^{1}$ & P $^{2}$ \\
\hline Gordura do leite na matéria seca $(\%)$ & $34,6 \pm 1,9$ & $23,2 \pm 0,8$ & $<0.001$
\end{tabular}

Gordura do leite na matéria seca (\%) $\quad 34,6 \pm 1,9 \quad 23,2 \pm 0,8 \quad<0.001$

${ }^{1}$ Os valores representam média $\pm \mathrm{SE}, \mathrm{n}=8$ parcelas/ tratamento no $15^{\circ}$ dia de lactação.

${ }^{2}$ Probabilidade de diferença entre os tratamentos. 


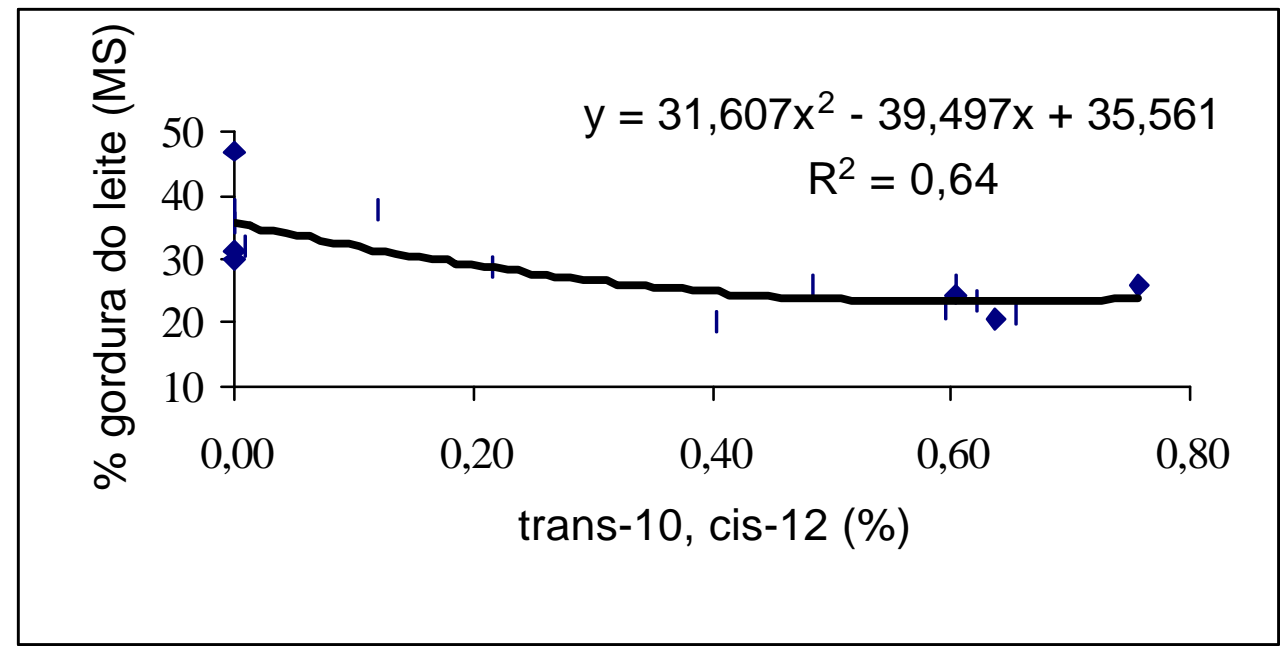

Figura 7 - Relação entre a diminuição na concentração de gordura e o conteúdo de trans10, cis-12 no leite no $15^{\circ}$ dia após a suplementação com CLA. Os valores representam cada animal $(\mathrm{n}=18)$.

\subsection{Perfil de ácidos graxos do leite.}

As alterações ocorridas no perfil de ácidos graxos no leite das ratas suplementadas com CLA foram consistentes com a redução no teor de gordura do leite e com os efeitos esperados do CA no metabolismo de lipídeos (Tabela 2). Na Figura 7, verificam-se diferenças para os ácidos graxos de cadeia média (C12:0 - C16:0), porém não foram observadas diferenças para a soma dos ácidos graxos de cadeia curta (C4:0 C10:0). Isto foi devido a ausência de efeito do CLA no ácido graxo C8:0, o qual é um dos maiores componentes nesta faixa de tamanho de cadeia de ácidos graxos. Pode-se verificar através da tabela 2, que o efeito do CLA é significativo sobre os ácidos graxos C4:0 e C6:0. Porém, a colaboração destes ácidos graxos na quantidade dos ácidos graxos de cadeia curta secretados no leite, é pequena. 
Tabela 3. Perfil de ácidos graxos no leite no $15^{\circ}$ dia de lactação.

\begin{tabular}{|c|c|c|c|c|c|}
\hline \multirow{3}{*}{$\begin{array}{c}\text { Ácido Graxo } \\
\text { (g/100g de gordura) }\end{array}$} & \multicolumn{4}{|c|}{ Tratamento } & \multirow{3}{*}{$\mathrm{P}^{2}$} \\
\hline & \multicolumn{2}{|c|}{ Controle } & \multicolumn{2}{|c|}{ CLA } & \\
\hline & Média $^{3}$ & $\mathrm{SE}^{3}$ & Média $^{3}$ & $\mathrm{SE}^{3}$ & \\
\hline C 4:0 & 0,08 & 0,01 & 0,04 & 0,01 & 0,03 \\
\hline C 6:0 & 0,23 & 0,01 & 0,28 & 0,01 & 0,04 \\
\hline C 8:0 & 4,9 & 0,33 & 5,2 & 0,26 & 0,45 \\
\hline C 10:0 & 13,4 & 0,53 & 12,2 & 0,49 & 0,1 \\
\hline C 12:0 & 10,6 & 0,25 & 8,8 & 0,34 & $<0,01$ \\
\hline C $12: 1$ & 0,21 & 0,03 & 0,15 & 0,02 & 0,17 \\
\hline C 14:0 & 10,26 & 0,41 & 8,18 & 0,32 & $<0,01$ \\
\hline C14:1 cis-9 & 0,07 & 0,00 & 0,07 & 0,00 & 0,22 \\
\hline C15:0 & 0,64 & 0,08 & 0,41 & 0,10 & 0,07 \\
\hline $\mathrm{C} 16: 0$ isso & 0,05 & 0,00 & 0,05 & 0,00 & 0,48 \\
\hline C16:0 & 21,26 & 0,64 & 19,6 & 0,31 & 0,03 \\
\hline C16: 1 cis-9 & 1,12 & 0,08 & 1,24 & 0,07 & 0,27 \\
\hline C18:0 & 3,43 & 0,08 & 3,64 & 0,06 & 0,05 \\
\hline C18:1 trans- 11 & 0,21 & 0,01 & 0,30 & 0,02 & $<0,01$ \\
\hline C18: 1 cis- 9 & 12,87 & 0,43 & 14,9 & 0,67 & 0,02 \\
\hline C18:2 trans- 11 , cis- 15 & 0,04 & 0,00 & 0,08 & 0,00 & $<0,01$ \\
\hline $\mathrm{C} 18: 2$ cis- 9, cis- 12 & 12,36 & 0,35 & 12,36 & 0,34 & 0,9 \\
\hline C18:3 & 0,92 & 0,07 & 1,06 & 0,03 & 0,09 \\
\hline CLA cis-9, trans- 11 & 0,12 & 0,03 & 0,73 & 0,04 & $<0,01$ \\
\hline CLA trans- 10 , cis- 12 & 0,04 & 0,02 & 0,6 & 0,03 & $<0,01$ \\
\hline CLA trans -9, trans- 11 & 0,02 & 0,00 & 0,09 & 0,00 & $<0,01$ \\
\hline \multicolumn{6}{|c|}{ Índice da dessaturase } \\
\hline C14:0/C14:1 & 155,2 & 13,2 & 113,8 & 9,6 & 0,02 \\
\hline C16:0/C16:1 & 20,1 & 0,9 & 16,2 & 2,4 & 0,14 \\
\hline C18:0/C18:1 & 0,27 & 0,01 & 0,25 & 0,01 & 0,11 \\
\hline
\end{tabular}

${ }^{1}$ Os ácidos graxos foram designados pelo número de átomos de carbono seguidos do número de duplas ligações.

${ }^{2}$ Probabilidade de diferença entre os tratamentos.

${ }^{3}$ Os valores representam média e SE, $\mathrm{n}=9$ parcelas/ tratamento. 
Ao contrário do que se observa em ruminantes, como encontrado por Medeiros (2002), o efeito do CLA na redução dos lipídeos do leite em roedores ocorre nos ácidos graxos de cadeia média (Yang et al., 2002; Loor et al., 2000). Neste experimento, este efeito confirmou-se a partir do ácido graxo de cadeia C10:0. Em ruminantes, o CLA afeta a porcentagem de ácidos graxos de cadeia curta, como o C4:0-C10:0, com um menor nível de significância no ácido graxo de cadeia C12:0. Nestes animais, o ácido graxo C14:0 representa uma grande porcentagem no perfil de ácidos no leite (quase a porcentagem da soma dos ácidos graxos de cadeia C4:0 a C12:0) e não é alterado pela dieta com CLA (Choinard et al., 1999). Talvez este seja o motivo de uma menor redução na porcentagem da gordura no leite $(-18 \%$ a $-28 \%)$ observada em alguns experimentos em ruminantes (Perfield et al., 2002; Medeiros, 2002) quando comparado às ratas. Nos roedores, em contraste com ruminantes, o CLA afeta a produção dos ácidos graxos de comprimento de cadeia altamente participativas na formação da gordura.

Além disso, observou-se que o tratamento com CLA aumentou a porcentagem do ácido graxo C18:0 (considerado ácido graxo de cadeia longa). Porém, este aumento não indicou que o CLA não inibiu a secreção de ácidos graxos de cadeia longa no leite pois o dado é percentual, isto é, se é reduzido o teor dos ácidos graxos de cadeia curta e média, necessariamente é aumentado o teor dos de cadeia longa.

Em vários trabalhos a produção de todos ácidos graxos é reduzida no leite de ruminantes após o tratamento com CLA (Loor \& Herbein, 1998; Medeiros, 2002, Perfield et al., 2002). Entretanto, os dados do presente experimento não nos permitem esta conclusão, em função da produção de leite dos animais não ter sido uma variável determinada, ainda que isso tivesse que representar um aumento de $33 \%$ na produção de leite, uma vez que o leite dos animais suplementados apresentou $33 \%$ a menos de gordura. 


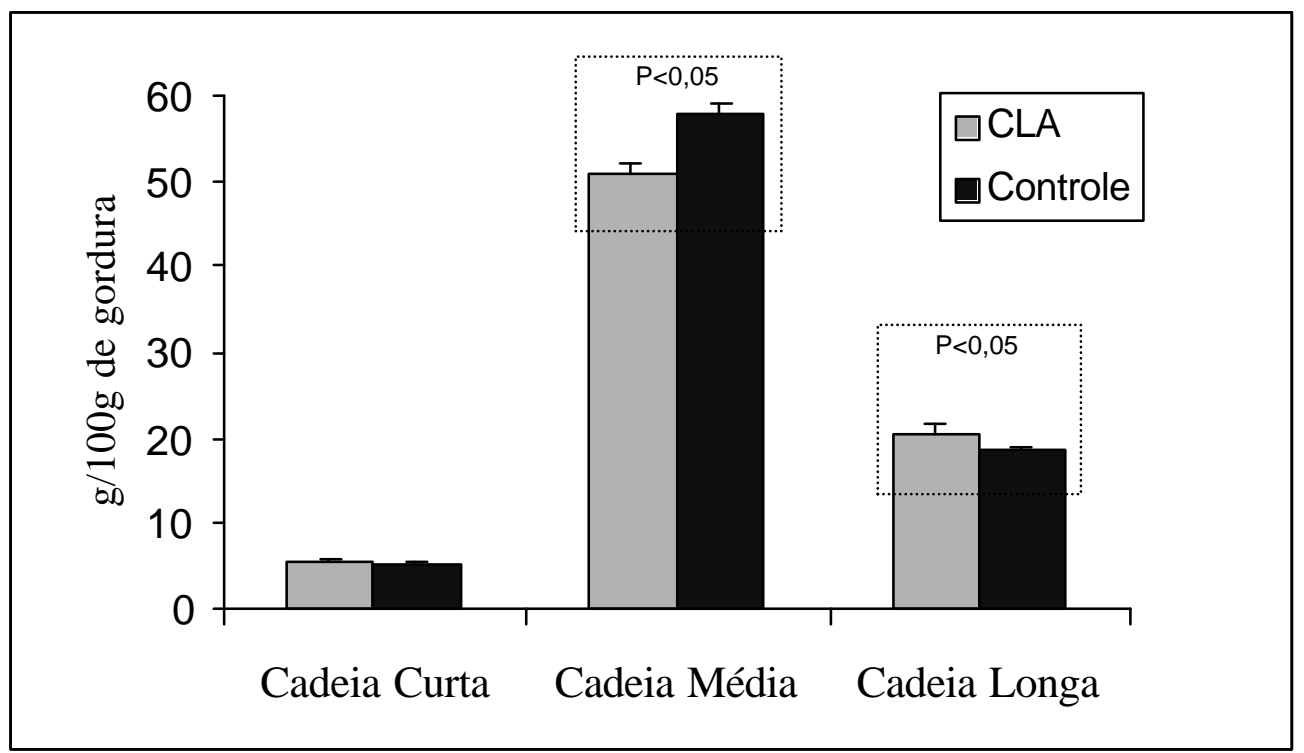

Figura 8 - Efeito do CLA sobre teor de ácidos graxos de cadeia curta (C4:0-C10:0), média $(\mathrm{C} 12: 0-\mathrm{C} 16: 0)$ e longa $(\mathrm{C} 18: 0)$ no leite. As barras representam média $\pm \mathrm{SE}, \mathrm{n}=9$ parcelas/ tratamento.

No período que foram coletadas as amostras de leite, as ratas estavam no pico da lactação. Segundo Williamson (1980), nesta fase da lactação, a glândula mamária sintetiza os ácidos graxos numa velocidade 5-10 vezes maior que o fígado, e neste período, a contribuição percentual da síntese de novo é predominante sobre a mobilização de reservas corporais para o total secretado.

O tratamento com CLA aumentou marcadamente seu conteúdo na gordura do leite (Figura 8). Houve um aumento de $600 \%$ na concentração do isômero cis-9, trans-11 e de $1500 \%$ na concentração do isômero trans-10, cis-12 no leite dos animais suplementados com CLA. Estimou-se a eficiência de recuperação dos isômeros de CLA contidos na mistura (isômeros excretados na gordura do leite em função da quantidade ingerida), esta foi de aproximadamente $8 \%$ para o isômero trans-10, cis-12 e de $14 \%$ para o isômero cis-9, trans-11 (Figura 9). Utilizou-se para se estimar este valor, uma produção de leite estimada para esta espécie, neste período da lactação, reportada por Willianson et al. (1995). Esta eficiência aparente foi maior em ratos do que as reportadas por Perfield et al. (2002) para ruminantes recebendo uma mistura de isômeros de CLA. 
Estes autores encontraram 3,4\% de eficiência para o isômero trans-10, cis-12. Entretanto, os valores encontrados neste trabalho são menores que os reportados previamente por Chouinard et al. (1999) os quais demonstraram que, através de infusões no abomaso de vacas lactantes, a maioria dos isômeros de CLA foi transferida para o leite de uma maneira dose-dependente. Entretanto, existiu uma diferença entre as eficiências de recuperação para cada isômero, pois apenas $10 \%$ do isômero trans-10, cis12 e $22 \%$ do isômero cis-9, trans-11 foram transferidos para o leite daqueles animais. Yang et al. (2002) baseando-se em análises realizadas por HPLC observaram que, a distribuição de isômeros do CLA presente no leite de roedores é um reflexo direto daqueles da dieta, uma vez que o CLA não é sintetizado em grande quantidade por animais não ruminantes.

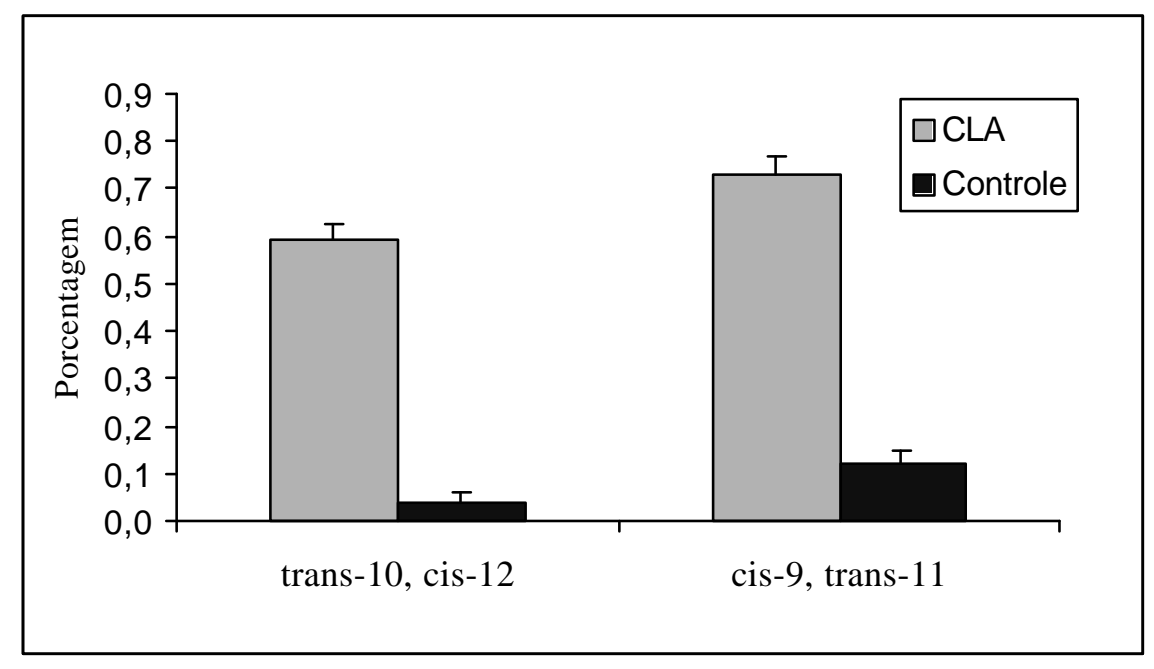

Figura 9 - Concentração (g/100g de lipídios) dos isômeros do CLA trans-10, cis-12 e cis-9, trans-11 no leite das ratas controle e CLA. As barras representam média $\pm \mathrm{SE}, \mathrm{n}=9$ parcelas/ tratamento. 


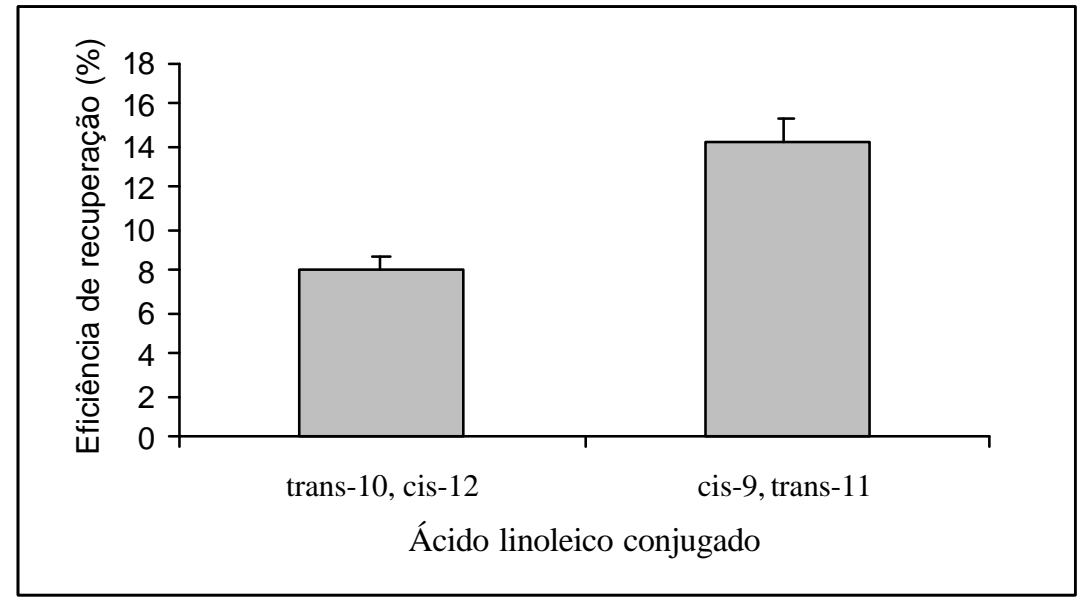

Figura 10 - Eficiência estimada de recuperação no leite dos principais isômeros do CLA (trans-10, cis-12 e cis-9, trans-11). Cada coluna representa a média $( \pm \mathrm{SE})$ de transferência, calculada no $15^{\circ}$ dia de lactação para 9 ratas recebendo a dieta suplementada com $2,5 \%$ de CLA.

Observa-se, através da figura 10 , que houve redução significativa na concentração de ácidos graxos saturados de cadeia média (C12:0, C14:0 e C16:0) e um aumento na concentração de ácidos graxos de cadeia longa saturada (C18:0) no leite dos animais que receberam tratamento CLA.

A enzima SCD exerce um papel essencial na manutenção da fluidez das membranas celulares através da introdução de uma dupla ligação na posição cis-9 (Los \& Murata, 1998). Em mamíferos, a SCD exerce um papel na manutenção da fluidez do leite (Kinsella, 1972). Neste trabalho, verificou-se que não houve alteração (Tabela 2) no índice da dessaturase (substrato/produto) para o C16:0/C16:1, C18:0/C18:1, porém verificou-se uma redução no valor do índice para C14:0/C14:1. Contudo, a ausência de efeito no índice dos ácidos graxos C16:0/C16:1 e C18:0/ C18:1 pode ser em função da baixa dosagem de CLA, visto que Peterson et al. (2002) e Baumgard et al. (2001) observaram que elevadas doses de CLA alteram o valor do índice da SCD, porém baixas doses não o afetam, embora sejam suficientes para reduzir a porcentagem de gordura no 
leite. Quando a atividade da SCD é marcadamente reduzida, por elevadas doses de CLA, efeitos na fluidez dos lipídios de membrana podem prejudicar a formação e secreção da gordura do leite e o turnover das membranas celulares. Isto poderia explicar o processo de apoptose observado em alguns experimentos in vitro realizados com elevadas concentrações de CLA em culturas de células (Ip et al. 1999b; Tsuboyama et al. 2000).

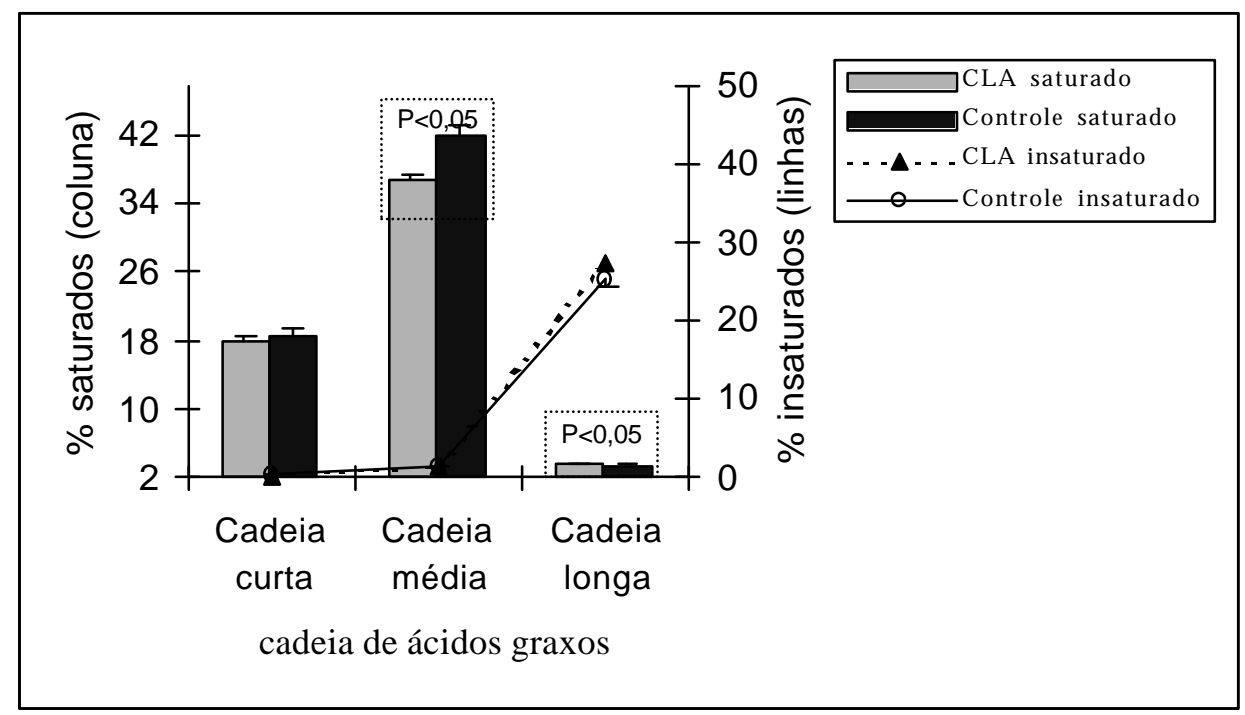

Figura 11 -Teores de ácidos graxos saturados de cadeia curta (C4:0, C6:0, C8:0 e C10:0), média (C12:0, C14:0 e C16:0) e longa (C18:0). As linhas representam a proporção de ácidos graxos insaturados dentro de cada grupo de comprimento de cadeia, sendo uma delas presente no carbono 9. Os valores estão expressos como média $\pm \mathrm{SE}, \mathrm{n}=9$ parcelas/ tratamento.

\subsection{Atividades enzimáticas: Glândula Mamária, Fígado e Tecido Adiposo}

A glândula mamária, durante a lactação, é considerada o sítio de lipogênese mais ativo. A velocidade de lipogênese na glândula é aproximadamente 5 vezes maior que no fígado (Williamson, 1980). Conseqüentemente, a atividade da FAS neste tecido deve ser bem menor do que a encontrada na glândula mamária, consistente com os resultados 
obtidos (Figura 12). A lipogênese depende da disponibilidade de substratos e cofatores, tais como o NADPH produzido pela via das Pentoses Fosfato (G6PDH e 6PGDH) e pela reação catalisada pela enzima NADP-malato desidrogenase (Foufelle et al., 1996). A FAS é regulada principalmente em nível gênico e, por este motivo, é a enzima chave no controle da velocidade da lipogênese, em longo prazo. Em médio prazo, tem-se a ACC que é regulada predominantemente por modificações covalentes (fosforilação) e controle alostérico (citrato, ácido graxo acil-CoA) (Semenkovich 1997).

A FAS, sendo crítica para a síntese de novo e podendo ser controlada tanto em nível transcricional, como pós-transcricional, em resposta a ação de nutrientes e hormônios foi utilizada para verificar se sua inibição faz parte do mecanismo através do qual o CLA reduz a secreção de gordura no leite, particularmente através da redução na síntese de ácidos graxos de cadeia média, como observado neste experimento. Conseqüentemente, as enzimas fornecedoras de NADPH também foram estudadas, pois o CLA deveria estar inibindo não só a atividade da FAS, como também a atividade das suas precursoras de cofatores.

A tabela 4 apresenta os valores das atividades enzimáticas expressas em nanomoles NADPH/mg $\operatorname{prot}^{-1}$. Verifica-se que, de acordo com o esperado, o tratamento com CLA afetou a atividade da FAS em todos os tecidos $(\mathrm{P}<0,05)$. O tratamento com CLA reduziu em 43\%, 69\% e 54\% a atividade desta enzima, na glândula mamária, fígado e tecido adiposo, respectivamente. A atividade das enzimas G6PDH e 6PGDH (precursoras de NADPH) também foram reduzidas na glândula mamária e fígado sendo $34 \%, 75 \%$, respectivamente para a G6PDH e em 27\%, 52\%, respectivamente para a 6PGDH. Porém, as atividades destas enzimas não foram reduzidas no tecido adiposo. Da mesma forma, a atividade da NADP-malato desidrogenase não foi modificada pela suplementação da dieta em nenhum tecido.

A produção de cofatores da FAS foi suficientemente grande, mesmo estando inibida neste experimento (Tabela 4). Em função deste dado, sabe-se que, embora o CLA afete a atividade das enzimas G6PDH e 6PGDH, a falta de cofatores não foi o motivo da redução da atividade da FAS (observada na Tabela 4). O CLA pode estar causando uma inibição na quantidade de transcrito desta enzima, como já foi observado 
em vacas (Baumgard et al., 2002b). Além disso, poderia estar causando uma inibição da acetil-CoA carboxilase através de ligação ao sítio alostérico, alteração no sítio catalítico ou no estado de fosforilação, inibindo assim a atividade da FAS por falta de malonil CoA. Mais estudos são necessários para se entender estes mecanismos de ação do CLA no metabolismo de gordura.

Em vacas Holandesas recebendo dietas DGL, Piperova et al. (2000) também observaram uma redução de $44 \%$ na atividade da FAS e de $61 \%$ na atividade da ACC. Esta redução foi acompanhada com o concomitante aumento do isômero do CLA trans10, cis-12 no leite. Consistente com estas observações, estes autores observaram reduções na porcentagem dos ácidos graxos de cadeia curta (sintetizados de novo) e uma redução na abundância do RNAm da ACC. Os resultados corroboram os efeitos do isômero trans-10, cis-12 na depressão da gordura no leite envolvendo a regulação da expressão de enzimas lipogênicas.

Posteriormente, Baumgard et al. (2002b) examinaram o mecanismo pelo qual o isômero trans-10, cis-12 inibe a síntese de gordura na glândula mamária. Foram verificadas reduções de 40\%, 39\% e 48\% na expressão da FAS, ACC e SCD, respectivamente. Adicionalmente, a expressão da LPL foi reduzida em $48 \%$ e da proteína ligadora de ácidos graxos também foi reduzida em 54\%. A expressão da glicerol fosfato acil transferase e acil glicerol fosfato acil transferase envolvidas na síntese de triglicerídeos foi reduzida em $40 \%$. Concluindo, estes dados demonstram que os mecanismos pelos quais o CLA trans-10, cis-12 inibiu a síntese de gordura no leite incluíram: diminuição da expressão de genes que codificam enzimas envolvidas no consumo de ácidos graxos circulantes e transporte, síntese de novo de ácidos graxos, dessaturação de ácidos graxos e síntese de triglicerídeos. 
Tabela 4. Valores da atividade enzimática das enzimas FAS, G6PDH, 6PGDH e NADPmalato desidrogenase na glândula mamária, fígado e tecido adiposo.

\begin{tabular}{|c|c|c|c|}
\hline & Glândul & mamária $\left(n=8^{3}\right)$ & \\
\hline Tratamento & $\frac{\text { Controle }^{1}}{\left(\text { nmoles/min mg } \text { prot }^{-1}\right)}$ & $\left.\frac{\text { CLA }^{1}}{(\text { nmoles/min mg prot }}{ }^{-1}\right)$ & $\mathbf{P}^{2}$ \\
\hline FAS & $35 \pm 2,0$ & $20 \pm 0,8$ & $<0.01$ \\
\hline G6PDH & $365 \pm 14$ & $239 \pm 14$ & $<0.01$ \\
\hline 6PGDH & $91 \pm 2,6$ & $66 \pm 2,9$ & $<0.01$ \\
\hline $\begin{array}{l}\text { NADP malato } \\
\text { desidrogenase }\end{array}$ & $121 \pm 4,4$ & $122 \pm 5,5$ & $>0.1$ \\
\hline
\end{tabular}

\begin{tabular}{|c|c|c|c|}
\hline \multicolumn{4}{|c|}{ Fígado $\left(n=5^{3}\right)$} \\
\hline Tratamento & Controle $^{1}$ & $\underline{C L A}^{1}$ & $\mathbf{P}^{2}$ \\
\hline & $\left(\right.$ nmoles $/ \min m g \operatorname{prot}^{-1}$ ) & $\left(\right.$ nmoles/min $m g \operatorname{prot}^{-1}$ ) & \\
\hline FAS & $16 \pm 0,7$ & $5 \pm 1,6$ & $<0.01$ \\
\hline G6PDH & $75 \pm 12$ & $19 \pm 8,1$ & $<0.01$ \\
\hline 6PGDH & $107 \pm 8,2$ & $51 \pm 13,6$ & $<0.01$ \\
\hline $\begin{array}{l}\text { NADP malato } \\
\text { desidrogenase }\end{array}$ & $22 \pm 2,8$ & $19 \pm 7,6$ & $>0.1$ \\
\hline
\end{tabular}

\begin{tabular}{|c|c|c|c|}
\hline \multicolumn{4}{|c|}{ Tecido adiposo $\left(n=4^{3}\right)$} \\
\hline Tratamento & Controle $^{1}$ & $\underline{\text { CLA }}^{1}$ & \\
\hline & $\left(\right.$ nmoles/min $\left.\mathrm{mg} \operatorname{prot}^{-1}\right)$ & $\left(\right.$ nmoles/min $\left.m g \operatorname{prot}^{-1}\right)$ & \\
\hline FAS & $1,1 \pm 0,22$ & $0,5 \pm 0,1$ & $<0.05$ \\
\hline G6PDH & $4,7 \pm 2,6$ & $1,35 \pm 2,2$ & $>0,1$ \\
\hline 6PGDH & $32 \pm 3,1$ & $25 \pm 2,1$ & $=0.1$ \\
\hline $\begin{array}{l}\text { NADP malato } \\
\text { desidrogenase }\end{array}$ & $11 \pm 2,5$ & $10 \pm 1,1$ & $>0.1$ \\
\hline
\end{tabular}

${ }^{1}$ média \pm SE.

${ }^{2}$ Probabilidade de diferença entre os tratamentos.

${ }^{3}$ número de repetições/ensaio. 
A figura 12 representa a atividade da FAS em cada tecido (glândula mamária, fígado e tecido adiposo) durante o pico da lactação nas ratas. Observa-se através da figura que neste estágio, a síntese de ipídeos é mais pronunciada na glândula mamária, seguida pelo fígado e tecido adiposo. E neste tecido, a síntese é quase zero uma vez que as ratas estão principalmente mobilizando as reservas corporais do que depositando lipídeos.

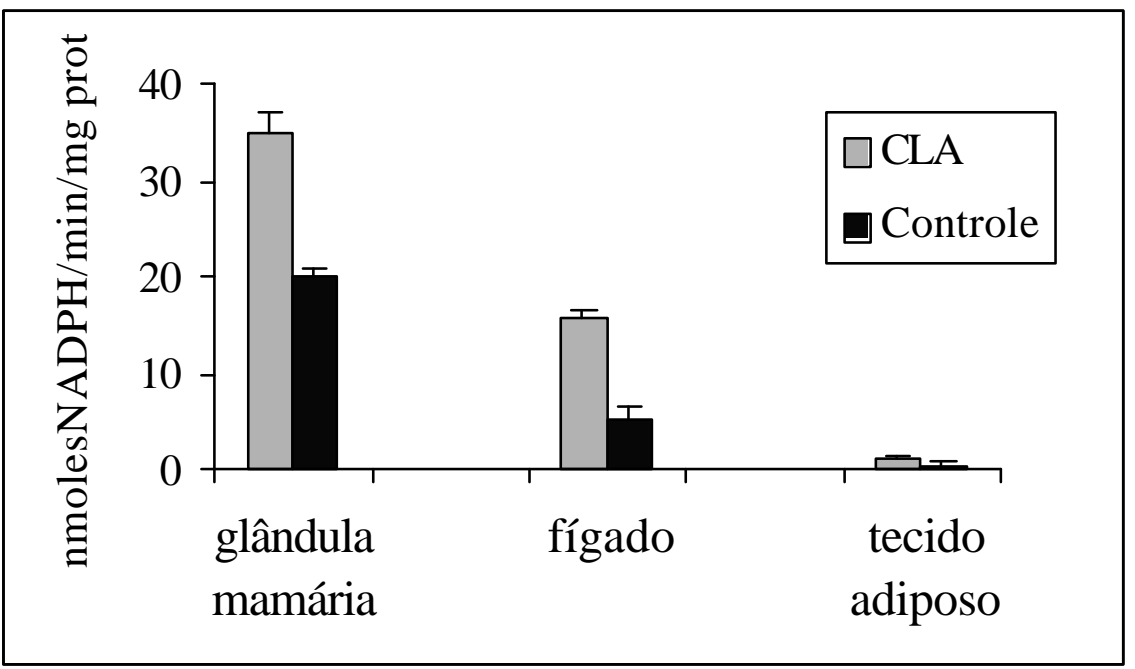

Figura 12 - Atividade da FAS nos tecidos lipogênicos durante a lactação. Valores expressos em nanomoles de $\mathrm{NADPH} / \mathrm{min} / \mathrm{mg}$ de proteína, média $\pm \mathrm{SE}$ para a glândula mamária de 8 animais, fígado de 5 e tecido adiposo de 4 . 


\section{CONCLUSÃO}

- O CLA reduz a concentração de gordura no leite dos animais. Os dados mostram que existe uma correlação inversa entre a concentração de trans-10, cis-12 secretada no leite e a concentração de gordura no leite.

- A suplementação de CLA na dieta promove a queda da concentração de ácidos graxos de cadeia média (C12:0 a C14:0) no leite.

- O leite das fêmeas suplementadas com CLA teve um aumento no teor dos isômeros trans-10, cis- 12 e de cis-9, trans- 11 .

- A atividade das enzimas lipogênicas; FAS, G6PDH e 6PGDH foram reduzidas na glândula mamária e fígado.Órgãos de maior atividade lipogênica.

- O CLA não afetou parâmetros lipídicos do sangue.

Resumindo;

Foi validado um modelo de ratas em lactação para estudo dos efeitos do CLA. O CLA reduziu a síntese de gordura na glândula mamária, alterando a atividade de enzimas lipogênicas e de enzimas que produzem cofatores e precursores para a lipogênese. Essa ação alterou o perfil de ácidos graxos do leite. A suplementação com CLA reduziu o ganho de peso da prole, possivelmente pela redução na síntese de lipídios e conseqüente redução na densidade energética do leite. 


\section{REFERÊNCIAS BIBLIOGRÁFICAS}

AZAIN, M.J.; HAUSMAN, D.B.; SISK, M.B.; FLATT, W.P. Dietary conjugated linoleic acid reduces rat adipose tissue cell size rather than cell number. Journal of Nutrition., v.130, p.1548-1554, 2000.

BANNI, S.; ANGIONI, E.; CASU, V.; MELIS, M.P.; CARTA, G.; CORONGIU, F.P.; THOMPSON, H.; IP, C. Decrease in linoleic acid metabolites as a potential mechanism in cancer risk reduction by conjugated linoleic acid. Carcinogenesis, v.20, p.1019-1024, 1999.

BANNI, S.; ANGIONI, E.; MURRU, E.; CARTA, G.; MELIS, M.P.; BAUMAN, D.; DONG, Y.; IP, C. Vaccenic acid feeding increases tissue levels of conjugated linoleic acid and suppresses development of premalignant lesion in rat mammary gland. Nutrition Cancer, v.41, p.91-97, 2001.

BAUMAN, D.E.; GRIINARI, J.M. Regulation and nutritional manipulation of milk fat: low-fat milk syndrome. Livestock Production Science, v.70, p.15-29, 2001.

BAUMGARD, L.H.; CORL, B.A.; BAUMAN, D.E. Effect of CLA isomers on fat synthesis during growth and lactation. In: CORNELL NUTRITION CONFERENCE, 62, Ithaca, 2000b. Proceedings. Ithaca: CORNELL UNIVERSITY, 2000b, p.180-188. 
BAUMGARD, L.H.; SANGSTER, J.K.; BAUMAN, D.E. Milk fat synthesis in dairy cows is progressively reduced by increasing supplemental amounts of trans-10, cis-12 conjugated linoleic acid (CLA). Journal of Nutrition, v.131, p.1764-1769, 2001.

BAUMGARD, L.H.; CORL, B.A.; DWYER, D.A.; BAUMAN, D.E. Effects of conjugated linoleic acids (CLA) on tissue response to homeostatic signals and plasma variables associated with lipid metabolism in lactating dairy cows. Journal of Animal Science, v.80, p.1285-1293, 2002a.

BAUMGARD, L.H.; CORL, B.A.; DWYER, D.A.; SAEBO. A.; BAUMAN, D.E. Identification of the conjugated linoleic acid isomer that inhibits fat synthesis. American Journal Physiology Regulatory Integrative Comparative Physiology, v.278, p.R179-R184, 2000a.

BAUMGARD, L.H.; MATITASHVILI, E.; CORL, B.A.; DWYER, D.A.; BAUMAN, D.E. Trans-10, cis-12 conjugated linoleic acid decreases lipogenic rates and expression of genes involved in milk lipid synthesis in dairy cows. Journal of Dairy Science, v.85, p.2155-2163, $2002 b$.

BEE. G. Dietary conjugated linoleic acid consuption during pregnancy and lactation influences growth and tissue composition in weaned pigs. Journal of Nutrition, v.130, p.2981-2989, 2000.

BLANKSON, H.; STAKKESTAD, J.A.; FAGERTUN, H.; THOM, E.; WADSTEIN, J.; GUDMUNDSEN, O. Conjugated linoleic acid reduces body fat mass in overweight and obese humans. Journal of Nutrition, v.130, p.2943-2948, 2000. 
BROWN, J.M.; HALVORSEN, Y.D.; LEA-CURRIE， Y.R.; GEIGERMAN， C.; McINTOSH. Trans-10, cis-12, but not cis-9, trans-11, conjugated linoleic acid attenuates lipogenesis in primary cultues of stromal vascular cells from human adipose tissue. Journal of Nutrition, v.131, p.2316-2321, 2001.

CHIN, S.F.; STORKSON J.M.; LIU, W.; ALBRIGHT, K.J.; PARIZA, M.W. Conjugated linoleic acid (9,11- and 10, 12- octadecadienóico acid) is produced in conventional but not germ-free rats fed linoleic acid. Journal of Nutrition, v.124, p.694-701, 1994a.

CHIN, S.F.; STORKSON, J.M.; ABRIGHT, K.J.; COOK, M.E.; PARIZA, M.W. Conjugated linoleic acid is a growth factor for rats as shown by enhanced weight gain and improved feed efficiency. Journal of Nutrition v.124, p.2344-2349, 1994b.

CHOI, Y.; PARK, Y.; PARIZA, M.W.; NTAMBI, J.M. Regulation of Stearoyl-CoA desaturase activity by the trans-10, cis-12 isomer of conjugated linoleic acid in hepG2 cells. Biochemical and Biophysical Research Communications , v.284, p.689-693, 2001.

CHOI, Y.; PARK, Y.; STORKSON, J.M.; PARIZA, M.W.; NTAMBI, J.M. Inhibition of stearoyl-CoA desaturase activity by the cis- 9 , trans-11 isomer and the trans-10, cis12 isomer of conjugated linoleic cid in MDA-MB-231 and MCF-7 human breast cancer cells. Biochemical and Biophysical Research Communications, v.294, p.785-790, 2002.

CHOUINARD, P.I.; CORNEAU, L.; BARBANO, D.M.; METSGER, L.E.; BAUMAN, D.E. Conjugated linoleic acids alter milk fatty acid composition and inhibit milk fat secretion in dairy cows. Journal of Nutrition, v.129, p.1579-1584, 1999a. 
CHOUINARD, P.Y.; BAUMAN, D.E.; CORL, B.A.; BAUMGARD, L.H.; MCGUIRE, M.A.; GIESY, J.G. An update on conjugated linoleic acid. In: CORNELL NUTRITION CONFERENCE FEED MANUFACTURERS, Ithaca, 1999b. Procedings. Ithaca: CORNELL UNIVERSITY, 1999b. p.93-101.

CHRISTIE, W.W. A simple procedure for rapid transmethylation of glycerolipids e cholesterol esters. Journal of Lipid Research, v.23: p.1072. 1982.

COOK, M.E.; DRAKE, B.M.; PARIZA, M.W. Derivatives of conjugated linoleic acid (CLA) and fat reduction. FASEB Journal, v.14, A525-A525, 2000.

CORL, B.A.; BAUMGARD L.H;. DWYER D.A.; GRIINARI, J.M.; PHILIPS, B.S;BAUMAN, D.E. The role of delta-9-desaturase in the production of cis-9, trans11. Journal of Nutritional Biochemistry, v.12, p.622-630, 2001.

DAVIS, C.L.; E BROWN, R.E. Low fat milk sindrome. In: DIGESTION AND METABOLISM IN RUMINANTS, Phillipson A.T., 1970. Anais. Newcastle: Oriel Press, 1970. 545p.

DELANY, J. P.; BLOHM, F.; TRUETT, A.A.; SCIMECA, J.A., WEST, D.B. Conjugated linoleic acid rapidly reduces body fat contend in mice without affecting energy intake. American Journal Physiology, v.276, p.R1172-R1179, 1999.

EVANS, M.E.; BROWN, J.M.; McINTOSH, M.K. Isomer-specific effects of conjugated linoleic acid (CLA) on adiposity and lipid metabolism. Journal of Nutritional Biochemistry, v.13, p.508-516, 2002. 
FOUFELLE, F.; GIRARD, J.; FERRÉ, P. Regulation of lipogenic enzymes expression by glucose in liver and adipose tissue: review of the potential cellular and molecular mechanisms. Advances in Enzyme Regulation, v.36, p.199-226, 1996.

GAYNOR, P.J.; WALDO, D.R.; CAPUCO, A.V.; ERDMAN, R.A.; DOUGLASS, L.W.; TETER, B.B. Milk fat depression, the glucogenic theory, and trans-C18:1 fatty acids. Journal of Dairy Science, v.78, p.2008-2015, 1995.

GIESY, J.G.; MCGUIRE, M.A.; SHAFII, B.; HANSON, T.W. Effect of dose of calcium salts of conjugated linoleic acid (CLA) on percentage and fatty acid content of milk fat in midlactation Holstein cows. Journal of Dairy Science, v.85, p.20232029, 2002.

GLOCK, G.E.; MCLEAN, P. Further studies on the properties and assay of glucose-6phosphate dehydrogenase and 6-phosphogluconate dehydrogenase of rat liver. Biochimie, v.55, p.400-408, 1953.

GORNALL, A.G.; BRADAWILL, C.T.; DAVID, M.M. Determination of serum protein by means of biuret reagent. Journal of Biological Chemistry, v.177, p.751$766,1949$.

GRIINARI, J.M.; CORI, B.; LACY, S.; CHOUINARD, P.; NURMELA, K.; BAUMAN, D. Conjugated linoleic acid is synthesized endogenously in lactating dairy cows by delta-9 desaturase. Journal of Nutrition, v.130, p.2285-2291, 2000.

GRIINARI, J.M.; CHOUINARD, P.Y.; BAUMAN, D.E. Trans fatty acid hipothesis of milk fat depression revised. In: CORNELL NUTRITION CONFERENCE, Ithaca, 1997. Proceedings. Ithaca: CORNELL UNIVERSITY, 1997, p.208-216. 
GRIINARI, J.M.; DWYER, D.A.; MCGUIRE, M.A.; BAUMAN, D.E.; PALMQUIST, D.L.; NURMELA, K.V.V. Trans-octadecenoic acids and milk fat depression in lactating dairy cows. Journal of Dairy Science, v. 81, p.1251-1261, 1998.

GRIINARI, J.M.; NURMELA, K.; DWYER, D.A.; BARBANO, D.M.; BAUMAN, D.E. Variation of milk fat concentration of conjugated linoleic acid and milk fat percentage is associated with a change in ruminal biohydrogenation Journal of Animal Science, v.77, Suppl, 1, 1999.

HA, Y.L.; GRIMM, N.K.; PARIZA, M.W. Anticarcinogens from fried ground beef: heat-altered derivatives of linoleic acid. Carcinogenesis, v.8, p.1881-1887, 1987.

HARA, A.; RADIN, N.S. Lipid extraction of tissues with low-toxicity solvent. Analytical Biochemistry, v.90, p. 420-426. 1978.

HARFOOT, C.G.; HAZLEWOOD, G.P. Lipid metabolism in the rumem. In: HOBSON, P.N. (Ed.). The rumen microbial ecosystem, New York: Elsevier, 1988, $527 \mathrm{p}$.

IGARASHI, M. MIYAZAWA, T. The growth inhibitory effect of conjugated linoleic acid on a human hepatoma cell line, HepG2, is induced by a change in fatty acid metabolism, but not the facilitation of lipid peroxidation in the cells. Biochemical et Biophysical Acta, v.1530, p.162-171, 2001.

INGLE， D.L.; BAUMAN， D.E.; MELLENBERGER， R.W.; JOHNSON， D.E. Lipogenesis in the ruminant: effect of fasting and refeeding on fatty acid synthesis and enzymatic activity of sheep adipose tissue. Journal of Nutrition, v. 103, p.1479-1488, 1973. 
IP, C. CLA and cancer prevention. In: INTERNATIONAL CONFERENCE ON CLA, 1., Alesund, 2001. Proceedings. Alesund: NATURAL ASA, 2001 p.8.

IP, C.; SCIMECA, J.A. Conjugated linoleic acid and linoleic acid are distictive modulators of mammary carcinogenesis. Nutrition Cancer, v.27, p.131-135, 1997.

IP, C.; SCIMECA, J.A.; THOMPSON, H.J. Conjugated linoleic acid. Cancer, v.74, p.1050-1054, 1994.

IP, C.; SCIMECA, J.A.; THOMPSON, H.J. Effect of timing and duraction of dietary conjugated linoleic acid on mammary cancer prevention. Nutrition Cancer, v.24, p.241-247, 1995.

IP, C.; CHIN, S.F.; SCIMECA, J.A.; PARIZA, M.W. Mammary cancer prevention by conjugated dienoic derivative of linoleic acid. Cancer Research, v.51, p.6118-6124, 1991.

IP, C.; JIANG, C.; THOMPSON, H.J.; SCIMECA, J.A. Retention of conjugated linoleic acid in the mammary gland is associated with tumor inhibition during the post - initiation phase of carcinogenesis. Carcinogenesis, v.18, p.755-759, 1997.

IP, C.; BANNI, S.; ANGIONI, E.; CARTA, G.; McGINLEY, J.; THOMPSON, H.J.; BARBANO, D.; BAUMAN, D. Conjugated linoleic acid-enriched butter fat alters mammary gland morphogenesis and reduces cancer risk in rats. Journal of Nutrition, v.129, p.2135-2142, 1999a.

IP, M.M.; MASSO-WELCH, P.A.; SHOEMAKER, S.F.; SHEA-EATON, W.K.; IP, C. Conjugated linoleic acid inhibits proliferation and induces apoptosis of normal rat mammary cells in primary culture. Experimental Cell Research, v.250, p.22-34, 1999b. 
IP, M.M.; MASSO-WELCH, P.A.; IP, C.; ZANGANI, D.; LEE, P. Inhibition of angiogenesis by CLA. In: INTERNATIONAL CONFERENCE ON CLA, 1., Alesund, 2001. Proceedings. Alesund: NATURAL ASA, 2001, p. 9.

KAY, J.K.; MACKLE, T.R.; AULDIST, M.J.; THOMSON, N.A.; BAUMAN, D.E. Endogenous synthesis and enhancement of conjugated linoleic acid in pasture-fed dairy cows. Proceedings of New Zealand Society Animal Production, v.62, p.12$15,2002$.

KEPLER, C.R.; HIRONS, K.P.;McNEILL, J.J.; TOVE, S.B. Intermediates and products of the biohydrogenation of linoleic acid by Butyrivibrio fibrisolvens. Journal of Biological Chemistry, v.241, p.1350-1354,1966.

KINSELLA, J.E. Stearoyl-CoA as a precursor of oleic acid and glycerolipids in mammary microsomes from lactating bovine: possible regulatory step in milk triglycerides synthesis. Lipids, v.7, p.349-355, 1972.

LEE, K.N.; PARIZA, M.W.; NTAMBI, J.M. Conjugated linoleic acid decreases hepatic stearoyl- CoA desaturase mRNA expression. Biochemical and Biophysical Research Communications, v.248, p.817-821, 1998.

LOOR, J.; FENAUX, M.; LIN. X.; HERBEIN, J.H. Influence of dietary CLA isomers and trans-vaccenic acid on body composition and fatty acid profiles in tissues of lactating mice. FASEB Journal, v.14, pA252-A252, 2000.

LOOR, J.J.; HERBEIN, J.H. Exogenous conjugated linoleic acid isomers reduce bovine milk fat concentration and yield by inhibiting de novo fatty acid synthesis. Journal of Nutrition, v.128, p.2411-2419, 1998. 
LOS, D.A.; MURATA, N. Structure and expresion of fatty acid desaturases. Biochemical et Biophysical Acta, v.1394, p.3-15, 1998.

MARTIN, S.A.; JENKINS, T.C. Factors affecting conjugated linoleic acid and transC18:1 fatty acid production by mixed bacteria. Journal of Animal Science, v.80, p.3347-33452, 2002.

MCGUIRE M.A.; GRIINARI J.M.; DWYER D.A.; BAUMAN, D.E. Role of insulin in the regulation of mammary synthesis of fat and protein. Journal of Dairy Science, v.78, p.816-824, 1995.

MCGUIRE, M.A; MCGUIRE, M.K.; MCGUIRE, M.S.; GRIINARI, J.M. Bovine Acid: The natural CLA. In: CORNELL NUTRITION CONFERENCE FEED MANUFACTURERS, 59., Ithaca, 1997. Proceedings. Ithaca: CORNELL UNIVERSITY, 1997, p. 217-226.

MEDEIROS, S.R. Ácido Linoléico Conjugado:Teores nos alimentos e seu uso no aumento da produção de leite com maior teor de proteína e perfil de ácidos graxos modificado. Piracicaba, 2002. 98p. Dissertação (Doutorado) Escola Superior de Agricultura “Luiz de Queiroz”, Universidade de São Paulo.

MELLEMBERGER, R.W.; BAUMAN, D.E., NELSON, D.R. Metabolic adaptations during lactogenesis. Biochemical Journal, v.136, p.741-748, 1973.

NATIONAL RESEARCH COUNCIL. Nutrient Requirements of the Laboratory Animals. Washington, DC: National Academic Press, 1978, 96p. 
OHNURI, K.; HARAMIZU, S.; OKI, K.; ISHIHARA, K.; FUSHIKI. A single oral administration of conjugated linoleic acid enhanced energy metabolism in mice. Lipids, v.36, p.583-587, 2001.

OSTROWSKA, E.; MURALITHARAN, M.; CROSS, R.F.; BAUMAN, D.F.; DUNSHEA, F.R. Dietary conjugated linoleic acid increase lean tissue and decrease fat deposition in growing pigs. Journal of Nutrition, v.129, p. 2037-2042, 1999.

PARIZA, M.W.; HARGRAVES, W.A. A beef-derived mutagenesis modulator inhibits initiation of mouse epidermal tumors by 7,12-dimethylbenz[a]anthracene. Carcinogenesis, v.6, p.591-593, 1985.

PARIZA, M.W.; HA, Y.L. Conjugated dienoic derivatives of linoleic acid: a new class of anticarcinogens. Medical Oncology Tumor Pharmacology, v.7, p.169-171, 1990.

PARIZA, M.W.; PARK, Y.; COOK, M.E. The biologically active isomers of conjugated linoleic acid. Progress in Lipid Research, v.40, p.283-298, 2001.

PARIZA, M.W.; ASHOOR, S.H.; CHU, F.S.; LUND, D.B. Effects of temperature and time on mutagen formation in pan-fried hamburguer. Cancer Letters, v.7, p.63-69, 1979.

PARIZA, M.W.; LORETZ, L.J.; STORKSON, J.M.; HOLLAND, N.C. Mutagens and modulator of mutagenesis in fried ground beef. Cancer Research, v.43, p. 2444s2446s, 1983.

PARK, Y.; ALBRIGHT, K.L.; LIU, W.; STORKSON, J.M.; COOK, M.E.; PARIZA, M.W. Effect of conjugated linoleic acid on body composition in mice. Lipids, v.32, p.853-858, 1997. 
PARK, Y.; STORKSON, J.M.; ALBRIGHT, K.J.; LIU, W.; PARIZA, M.W. Evidence that the trans-10, cis-12 isomer of conjugated linoleic acid induces body composition changes in mice. Lipids, v.34, p.235-241, 1999.

PARK, Y.; STORKSON J.M.; NTAMBI, J.M.; COOK, M.E.; SIH, C.J.; PARIZA, M.W. Inhibition of hepatic stearoyl-CoA desaturase activity by trans-10, cis-12 conjugated linoleic acid and its derivates. Biochemical et Biophysical Acta, v.1486, p.285-292, 2000.

PENINGTON, J.A.; DAVIS, C.L. Effects of intraruminal and intraabomasal additions of cod liver oil on milk fat production in the cow. Journal of Dairy Science, v.58, p.49-55, 1975.

PERFIELD J.W.; BERNAL-SANTOS, G.; OVERTON, T.R.; BAUMAN, D.E. Effects of dietary supplementation of rumen-protected conjugated linoleic acid in dairy cows during established lactation. Journal of Dairy Science, v.85, p.2609-2617, 2002.

PETERS, J.M.; PARK, Y.;GONZALEZ, F.J.; PARIZA, M.W. Influence of conjugated linoleic acid on body composition and target gene expression in peroxisome proliferator-activated receptor $\alpha$-null mice. Biochemical et Biohysical Acta, v.1533, p.233-242, 2001.

PETERSON, D.G.; BAUMGARD, L.H.; BAUMAN, D.E. Short communication: Milk fat response to low doses of trans-10, cis-12 conjugated linoleic acid (CLA). Journal of Dairy Science, v.85, p.1764-1766, 2002. 
PIPEROVA, L.S.; SAMPUGNA, J.; TETER, B.B.; KALSCHEUR, K.F.; YURAWECZ, M.P.; KU. Y.; MOREHOUSE, K.M.; ERDMAN, R.A. Duodenal and milk trans octadecenoic acid and conjugated linoleic acid (CLA) isomers indicate that postabsortive synthesis is the predominant source of cis-9-containing CLA in Lactating Dairy cows. Journal of Nutrition, v.132, p.1235-1241,2002.

PIPEROVA, L.S.; TETER, B.B.; BRUCKENTAL, I.;SAMPUGNA, J.; MILLS, S.T.; YURAWECZ, M.P.; FRITSCHE, J.; KU, K.; ERDMAN, R.A. Mammary lipogenic enzyme activity, trans fatty acids and conjugated linoleic acids are altered in lactating dairy cows fed a milk fat - depressing diet. Journal of Nutrition, v.130, p.2568 $2574,2000$.

POULOS, S.; SISK, M.; HAUSMAN, D.B.; AZAIN, M.J.; HAUSMAN, G.J. Pré- and postnatal dietary cojugated linoleic acid alters adipose development, body weight gain and body composition in Sprague- Dawley rats. Journal of Nutrition, v.131, p.2722-2731, 2001.

RAHMAN, S.M.; WANG, Y.M.; YOTSUMOTO, H.; CHA, J.Y.; HAN, S.Y.; INOUE, S.; YANAGITA, T. Effects of cojugated linoleic acid on serum leptin concentration, body-fat accumulation, and $\beta$-oxidation of fatty acid in OLETF rats. Nutrition, v.17, p.385-390, 2001.

SAS INSTITUTE SAS/STAT ${ }^{\mathrm{TM}}$ Guide for personal computers . Cary: 2000. p.1v.

SCIMECA, J.A. Toxicological evaluation of dietary conjugated linoleic acid in male Fischer 344 rats. Food and Chemical Toxicology, v.36, p.391-395, 1998.

SEBEDIO, J.L.; GNAEDIG, S.; CHARDIGNY, J. Recent advances in conjugated linoleic acid research. Current Opinion in Clinical Nutrition Metabolic Care, v.2, p.499-506, 1999. 
SEMENKOVICH, C.F. Regulation of Fatty acid synthase (FAS). Progress in Lipid Research, v.36, p.43-53, 1997.

SMITH, S.B.; HIVELY, T.S.; CORTES, G.M.; HAN, J.J.; CHUNG, K.Y.; CASTENADA, P.; GILBERT, C.D.; ADAMS, V.L.; MERSMANN, H.J. Conjugated linoleic acid depresses the delta 9 desaturase index and stearoyl coenzima A desaturase enzyme activity in porcine subcutaneous adipose tissue. Journal of Animal Science, v.80, p.2110-2115, 2002.

SUTTON, J.D. Altering milk composition by feeding. Journal of Dairy Science, v.72, p.2801-2814, 1989.

TERPSTRA, A.H.M., BEYNEN, A.C.; EVERTS,S.; KOCSIS, S.; KATAN, M.B.; ZOCK, P.L. The decrease in body fat mice fed conjugated linoleic acid is due to increases in energy expenditure and energy loss in the excreta. Journal of Nutrition, v.132, p.940-945, 2002.

THOMPSON, H.; ZHU, Z.; BANNI, S.; DARCY, K.; LOFTUS, T.; IP, C. Morphological and biochemical status of the mammary gland as influenced by conjugated linoleic acid: implications for a reduction in mammary cancer risk. Cancer Research, v.15, p.5067-5072, 1997.

TSUBOYAMA- KASAOKA, N.; TAKAHASHI, M.; TANEMURA, K.; HYOUN-JU, K.; TANGE, T.; OKUYAMA, H.; KASAI, M.; IKEMOTO, S.; EZAKI, O. Conjugated linoleic acid supplementation reduces adipose tissue by apoptosis and develops lipodystrophy in mice. Diabetes, v.49, p.1334-1542, 2000.

VAN SOEST, P.J. Nutritional Ecology of the Ruminant. 2 ed. Ithaca: CORNELL UNIVERSITY, 1994. 476p. 
WEST, D.B.; BIOHM, F.Y.; TRUETT, A.A.; DE LANY, J.P. Conjugated linoleic acid persistently increases total expenditure in $\mathrm{AKR} / \mathrm{J}$ mice increasing uncoupling protein gene expression. Journal of Nutrition, v.130, p.2471-2477, 2000.

WILLIAMSON, B.D.; LUND, P.; EVANS, R.D. Substrate selection and uptake by lactating mammary gland. Proceedings in Nutrition Society, v.54, p.165-175, 1995.

WILLIAMSON, D. H. Integration of metabolism in tissues of the lactanting rat. FEBS Letters, v.117, p.K93-K103, 1980.

YANG, A.; LARSN, T.W.; SMITH, S.B.; TUME, R.K. Delta 9 dessaturase activiy in bovine subcutaneous adipose tissue of different fatty acid composition. Lipids, v.34, p.971-978, 1999.

YANG, L.; YEUNG, Y.V.; HUANG, Y.; WANG, H.Q.; CHEN, Z. Preferencial incorporation of trans-conjugated linoleic acid isomers into the liver of suckling rats. British Journal of Nutrition, v.87, p.253-260, 2002.

YURAWECZ, M.P.; KRAMER, J.K.G.; MOSSOBA, M.M.; ROACH, J.A.G.; SEHAT, N.; EULITZ, K.; FRITSCHE, J.; KATAOKA, A.; KU, Y. Analytical methodology for CLA. In: INTERNATIONAL CONFERENCE ON CLA,1., Alesund, 2001. Proceedings. Alesund: NATURAL ASA, 2001, p. 14.

ZHANG, A.; CHEN, Z.Y. Oxidative stability of conjugated linoleic acids relative to other polyunsaturated fatty acids. Journal of American Oil Chemitry Society, v.74, p.1611-1613, 1997. 